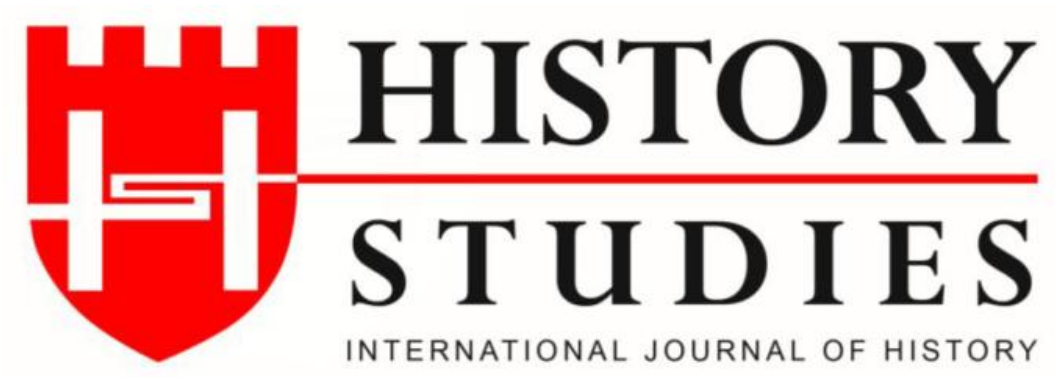

ISSN: 13094173 (Online) 1309 - 4688 (Print)

Volume 12 Issue 5, October 2020

DOI Number: 10.9737/hist.2020.942

Araştırma Makalesi

Makalenin Geliş Tarihi: 13.08.2020 Kabul Tarihi: 18.09.2020

Atıf Künyesi: İlker Cender, “İkinci Dünya Savaşındaki Mihver İlerleyişinin Türk Dış Politikasına

Etkilerinin İngiliz The Times Gazetesine Yansımaları", History Studies, 12/5, Ekim 2020, s. 2771-2796.

\title{
İkinci Dünya Savaşındaki Mihver İlerleyişinin Türk Dış Politikasına Etkilerinin İngiliz The Times Gazetesine Yansımalart
}

\section{The Effects of The Axis Advance During The Second World War on Turkish Foreign Policy As Reflected By The English Newspaper The Times}

\author{
Dr. İlker Cender \\ ORCID No: 0000-0002-6312-3839 \\ Ondokuz Mayıs Üniversitesi
}

$\ddot{O} z$

İkinci Dünya Savaşı'nda, Almanya etrafında oluşan Mihver bloğunun savaşın ilk yıllarında Avrupa'da elde ettiği üstünlük bu dönemde Türk dış politikasını şekillendiren temel unsur olmuştur. Türkiye kendisini savaşın dişında tutmak için günün getirdiği her türlü aracı ustalıkla kullandı ve İngiltere ile ittifak, Almanya ile de dostluk antlaşmaları imzalayabildi. Mihver Devletlerinin Avrupa'da elde ettiği her bir başarı bir yandan Türkiye'nin çevresindeki çemberi daraltırken, diğer yandan da Türkiye'nin yeni stratejiler geliştirmesini zorunlu kıldı. Bu stratejiler, Mihver Devletlerinden gelen taleplerin yantlanmasından, Müttefiklerden gelen baskıların karşılanmasına kadar olan geniş bir yelpazedeki sorunların aşılması için bir temel teşkil etti. İngiltere'nin en köklü gazetelerinden olan ve bu dönemde İngiltere'de iktidarda bulunan Mutabakat Hükümeti'nin görüşlerini yansıtan The Times gazetesi, Türkiye ile ilgili yaptığı haberlerde hem İngiliz hükümetinin hem de kamuoyunun görüşlerini yansıtmaktadır. Bu bağlamda, gazetenin Türkiye'ye yönelik olarak geliştirdiği söylemler de savaşın seyrine paralel olarak değişiklik göstermektedir.

Anahtar Kelimeler: İkinci Dünya Savaşı, Türk Dış Politikası, Mihver, İngiltere, The Times

\section{Abstract}

The domination of the Axis bloc formed around Germany in Europe in the first years of the Second World War was the main factor which shaped the Turkish foreign policy in this period. Turkey was able to use every possible means to keep herself out of the war and signed an alliance treaty with Britain on one hand and a treaty of friendship with Germany on the other. However, each victory on the side of the Axis narrowed the circle around Turkey and forced Turkey to develop new strategies. These strategies formed such a sound 
İkinci Dünya Savaşındaki Mihver İlerleyişinin Türk Dış Politikasına Etkilerinin...

basis to meet a wide variety of demands from both the Axis Powers and the Allies. The Times, one of the oldest newspapers in England, reflected both the policies of the government and the views of the public about Turkey. Thus, the discourse adapted by the newspaper in its news changed with the course of the war.

Keywords: Second World War, Turkish Foreign Policy, Axis, England, The Times

\section{Giriş}

18. yüzyılda temelleri atılan, 19. yüzyılda ise büyük bir ivme kazanarak insanoğlunun dünya üzerindeki egemenliğini daha önceden görülmemiş bir hızla yayan Sanayi Devrimi, kendisini gerçekleştiren topluluklar için beraberinde önce refah, sonrasında ise bu refahın paylaşılmasında ortaya çıkan sorunların yol açtığı siyasi ve askeri çatışmalar getirmiştir. Bu çatışmalar 20 . yüzyılın başına kadar yerel düzeyde kalırken, 1914 yılı dünya savaşlarının ilkinin başladığı yıl olarak sonsuza kadar lanetlenmiştir. Sermaye, emek, hammadde, sömürge ve barut kokusunun oluşturduğu sel 4 yıl boyunca Avrupa kıtasını yakıp yıktıktan sonra yuttuğu milyonlarca yaşam ile birlikte yer altına, belki de Dante'nin Cehennemi'ne doğru kaybolup gitmiştir. O gittiğinde ise, arkasında bir tarafta tüm bu yıkıntıyı anlamlandırmaya çalışan öfkeli topluluklar, diğer tarafta ise Büyük Savaş sonucunda galip gelmelerinin ödülünü mağlup devletlerle yaptıkları anlaşmalar yoluyla tahsil etmeye çalışan mağrur topluluklar bırakmıştır.

Söz konusu topluluklardan öfkeli olanlar bir yandan ekonomik, sosyal ve askeri yaralarını sarmakla uğraşırken, kendi içlerinde yükselen aşırı milliyetçi söylemleri de kontrol altında tutmaya çalışıyordu. Revizyonist olarak adlandırılan bu devletler adlarının da işaret ettiği üzere, 1. Dünya Savaşı'ndan sonra aleyhlerine gelişen durumu düzeltmek istiyorlardı. Bu istek, 2. Dünya Savaşı'nın en önemli aktörü olacak olan Almanya Cumhuriyeti'nde 1918 yılında kurulan Alman İşçi Partisi'nin 1920'de Nasyonal Sosyalist Alman İşçi Partisi'ne (Nazi Partisi) evrilmesi ile şekillenecek ve 30 Ocak 1933'de Nazi Partisi'nin Adolf Hitler önderliğinde iktidara gelmesi ile artık somut bir hal alacaktır.

Revizyonist kanadın bir diğer önemli devleti olan İtalya'da ise, 30 Ekim 1922 tarihinde iktidara gelen faşist partisinin lideri Mussolini, 1. Dünya Savaşı'nda haksızlığa uğradığını düşünüyor ve bunu telafi etmenin yollarını arıyordu. Almanya'da Nazilerin iktidara gelmesi ve İspanya'da Franco faşizminin yükselişe geçmesiyle dış destek bulan İtalya 1930'larda dış politikasında daha saldırgan olmaya başladı. ${ }^{1}$ Bu bağlamda, 1935 Ekim'inde Habeşistan, 1939 Nisan'ında da Arnavutluk İtalya tarafından işgal edilmiş ve uluslararası kamuoyu bu iki işgale de adeta seyirci kalmıştır. Yukarıda belirtilen 22 Mayıs 1939 tarihli Stahlpakt'ın Almanya ile imzalanması ise İtalya'nın gelecekte izleyeceği politikaların bir habercisi olacaktır. Stahlpakt, kendi etrafında oluşan küresel boyuttaki siyasi ve askeri saldırganlığın çekirdeğini oluşturarak, Mihver bloğuna evrildi.

Latince kökenli bir terim olan statüko (statu que), yürürlükte bulunan antlaşmalara göre olması gereken veya süregelen durum anlamına gelmektedir. ${ }^{2}$ İki dünya savaşı arasındaki

\footnotetext{
1 İlhan Uzgel, “İtalya'yla İlişkiler”, Türk Dış Politikası, Ed. Baskın Oran, İletişim Yayıncılık, İstanbul 2003, s. 293295.

${ }^{2}$ Türkçe Sözlük, Türk Dil Kurumu, Ankara 2011, s. 2160.
} 
dönemde mevcut durumu korumak için revizyonist devletlerin talepleri karşısında daha çok alttan alma ve oyalama gibi siyasi taktikler kullanan anti-revizyonist devletler İngiltere ve Fransa'nın önderliğinde uluslararası siyaset sahnesinde adımlarını atıyorlardı.

İki Dünya Savaşı arasındaki dönem, Avrupa'da Versailles Antlaşması'nın oluşturduğu statükoyu korumaya çalışan İngiltere ile Fransa'nın öncülügündeki anti-revizyonist devletler grubu ile Versailles Antlaşması'nın değiştirilmesini amaçlayan ve Almanya ve İtalya'nın öncülük ettiği devletler grubu arasındaki siyasal, diplomatik, ekonomik, kültürel/ideolojik ve nihayet askeri mücadele tarihidir. ${ }^{3}$

Versailles Antlaşması ile Almanya karşısında zaferlerini tescil ettiren İngiltere ve Fransa, 1938 yılının Eylül ayında kendilerini Hitler tarafından adeta dikte ettirilen Münih Antlaşmasını imzalarken bulmuşlardır. Hitler'in 1933 yılından bu yana izlediği agresif dış politikayı iyi tahlil edemeyip, saldırganlıklara göz yuman İngiltere ve Fransa'nın başbakanları Chamberlain ve Daladier bu tutumlarının sonuçlarını, birincisi savaşın patlak vermesinden kısa bir süre sonra başbakanlığı kaybetmesi ile, ikincisi ise Fransa'nın Almanya tarafından işgal edildiği tarihte başbakan olma payesi ile ödeyecektir.

Bu iki blok içerisinde de yer almayan S.S.C.B., İtalya ve Almanya'nın gittikçe saldırgan bir politikaya meyletmeleri karşısında İngiltere ve Fransa ile yakınlaşmaya çalışmıştır. Ancak, İngiltere ve Fransa'nın S.S.C.B. ile bir türlü gerçek bir yardım anlaşması imzalamaması Sovyet lider Stalin'i Almanya'ya yakınlaştırmıştır. 2. Dünya Savaşı'ndan sonra dünya düzenini belirleyecek olan Soğuk Savaş dönemi boyunca etkili olacak Sovyet kuşkuculuğunun temelleri bu dönemde atılmıştır. Stalin İngiltere ve Fransa'nın Almanya'yı sürekli tahrik edip, S.S.C.B. üzerine saldırtmaya çalıştığını düşünüyordu. Bu durumu 10 Mart 1939 tarihli Komünist Parti 18. Kongresi'nde açıkça dile getirmiştir: "...Fransa ve İngiltere, Avusturya ve Çekoslovakya'yı feda ederek, Almanları gittikçe doğuya doğru itmekte, ona kolay bir av vaat ederek, Bolşeviklerle bir savaş başlatın, diğer her şey kendiliğinden halledilecektir, demektedir. Bu adeta bir teşvike benzemektedir." B Böylece, 23 Ağustos 1939 tarihli Alman-Sovyet Saldırmazlık Antlaşması 2. Dünya Savaşı'nın temeline konulan en son taş olmuştur.

Birinci Dünya Savaşı'na giren Rusya, Avusturya-Macaristan ve Osmanlı İmparatorlukları gibi köklü imparatorluklar bu savaşın sonunda yıkılmışlar ve bunların yerine çok sayıda ulusdevlet Avrupa sahnesine çıkmıştır. 29 Ekim 1923 tarihinde kurulan Türkiye Cumhuriyeti 2. Dünya Savaşı'nın arifesinde vefat eden Mustafa Kemal Atatürk önderliğinde kendi ayakları üzerinde durmaya çalışan bir devlettir. Cumhuriyet'in kuruluşundan İkinci Dünya Savaşı'nın patlak vermesine kadar on altı yıl geçtiği halde, savaşın başında Türkiye ancak çok c1lız ekonomik kalkınma kaydedebilmişti. Bunun başlıca nedeni, gerçek ekonomik büyümeye geçilmeden önce tarımda ve sanayide uzun bir onarım döneminin yaşanmasıyd $1 .{ }^{5} \mathrm{Bu}$ onarım dönemi Türkiye'yi savaş konusunda ihtiyatlı politikalar izlemeye yöneltmiş ve 2. Dünya Savaşı öncesinde çevresinde bir güvenlik çemberi oluşturmak amacı ile bölgesindeki devletler ile

${ }^{3}$ Cemil Koçak, Türkiye'de Milli Şef Dönemi (1938-1945) Cilt 1, İletişim Yayınları, İstanbul 2003, s. 232.

${ }^{4}$ Kamuran Gürün, Türk-Sovyet İlişkileri (1920-1953), Türk Tarih Kurumu Basımevi, Ankara 1991, s. 169-184.

5 Selim Deringil, Denge Oyunu İkinci Dünya Savaşı'nda Türkiye’nin Dış Politikası, Tarih Vakfı Yurt Yayınları, İstanbul 2009, s. 13. 
İkinci Dünya Savaşındaki Mihver İlerleyişinin Türk Dış Politikasına Etkilerinin...

saldırmazlık, dostluk ve güven anlaşmaları imzalamıştır. Bunlar arasında 1925 yılında Sovyetler ile imzalanan Dostluk ve Saldırmazlık Antlaşması, 1932 yılında Milletler Cemiyeti'ne üye olunması, 1934 tarihli Balkan Antant1, 1936 yılında Türkiye'nin boğazlardaki egemenliğini tanıyan Montreux Sözleşmesi, Türkiye, İran, Irak ve Afganistan arasında 1937'de imzalanan Sadabat Paktı Türk dış politikasının savaş dışı kalma özelliğini göstermektedir. Türkiye 1. Dünya Savaşı sonunda imzaladığ Lozan Antlaşması'nın çözümsüz bıraktığı konuları da yine barışçıl yollardan çözmeye çalışmış ve bu bağlamda İngiltere ile Musul sorunu 1925 yılında aleyhinde, Fransa ile Hatay sorunu ise 1939 yılında lehinde sonuçlanmıştır.

Hitler'in 1933 y1lında iktidara gelmesinden sonra, Almanya Türkiye'nin ekonomik kalkınma hareketine katkıda bulunmuş ve bu dönemde dış finansman kaynaklarına büyük gereksinim duyan Türkiye de Almanya ile sıkı bir ekonomik işbirliğine gitmekte bir sakınca görmemiştir. Ancak 1936 yılında Berlin-Roma Mihveri’nin kurulması ve İtalya'nın Arnavutluk’u işgali Türkiye'nin İngiltere ve Fransa'ya bağlanmasına neden olmuştur. ${ }^{6}$

Türkiye, savaşın ayak seslerinin duyulmaya başlandığı dönemden, savaşın Müttefik zaferi ile sonlanacağının kesinleştiği son birkaç aya kadar hem Müttefikler hem de Mihver Devletleri açısından büyük önem taşımıştır. Bu önem, Türkiye'nin sahip olduğu stratejik ve coğrafi konumuna atfedilebileceği gibi, savaşan tarafların onun bu özelliklerini nasıl değerlendirdikleri ile de yakından ilişkilidir. Bu bağlamda, Türkiye Cumhuriyeti'nin İkinci Dünya Savaşının ilk yıllarında Almanya liderliğindeki Mihver devletlerinin Avrupa'da elde ettiği üstünlük tarafından şekillendirilen dış politikasını anlamak, söz konusu dönemde dünyadaki Türkiye algısını tespit açısından değerli veriler sunacaktır. 1785 yılında yayın hayatına başlayan ve İngiltere'nin en köklü gazetelerinden olan The Times'ın arşivi bu bakımdan önemlidir. Hiç şüphesiz, gazeteler dönemlerinin politik anlayışlarını, devletlerinin izlediği politikaları ve kamuoyuna hakim görüşleri yansıtmaları bakımından oldukça değerlidir. Bu değer, savaş gibi olağanüstü bir dönemde gazetelerin hükümetlerin sözcüsü konumuna yükselmeleri ile daha da artmaktadır. Bu nedenle, tarihi boyunca genel olarak İngiliz siyasetinin Muhafazakar kanadını destekleyen The Times gazetesinin bu dönemde Türkiye ile ilgili olarak yayınladığı haberleri okurken ve analiz ederken, bunların aynı zamanda söz konusu dönemde İngiltere'de iş başında olan Milli Mutabakat hükümetinin politikalarının yarı resmi yansımaları olduğu da unutulmamalıdır.

\section{Savaşın Başlaması}

Uluslararası sistemde temel bir çelişki vardır. Modern tarihte hemen hemen hiçbir devlet "savaş̧̧ı" bir dış politika izlediğini iddia etmemiş ve etmemektedir. Hitler Avrupa'yı ateşe verirken amacının Avrupa'ya barış getirmek olduğunu söylemişti. ${ }^{7}$

Hitler'in daha 3 Nisan tarihli ilk “Beyaz Durum” emrinde tespit ettiği 1 Eylül 1939 günü şafak vakti Alman Orduları Polonya sınırına doğru akmışlar; Varşova'ya kuzeyden, güneyden ve batıdan yaklaşmaya başlamışlardı. ${ }^{8}$ Yıllardan beri savaş hazırlıkları yapan Alman orduları karşısında Polonya'nın modern silahlardan yoksun ve hala 19. yüzyıl tarzı süvari birliklerine

${ }^{6}$ Hüner Tuncer, İsmet İnönü'nün Dış Politikası (1938-1950), Kaynak Yayınları, İstanbul 2012, s. 30.

${ }^{7}$ Oral Sander, Türkiye'nin Dış Politikası, İmge Kitabevi, Ankara 2000, s. 131.

${ }^{8}$ William L. Shirer, Nazi Imparatorluğu Doğuşu, Yükselişi, Çöküşü, Çev: Rasih Güran, İnkılap Kitabevi, İstanbul 1992, s. 757. 
güvenen ordusu ile fazla tutunamayacağı ilk günlerden ortaya çıkmıştır. Almanların 2. Dünya Savaşı'na damga vuracak olan Blitzkrieg (Yıldırım Savaşı) taktiği de böylece ilk kez denenmiş oluyordu.

İngiltere ve Fransa Polonya'ya vermiş oldukları garantilere rağmen, Alman saldırısı karşısında somut bir adım atamamış ve 3 Eylül günü önce İngiltere'nin, sonra da Fransa'nın Almanya'ya savaş ilan etmesi ile yetinmişlerdir.

Türkiye, İngiltere ile Mayıs ayında, Fransa ile Haziran ayında imzaladığı ortak deklarasyonlar ile bu savaşta hangi tarafta olduğunu belirlemişti. Bu durum, 4 Eylül 1939 tarihli The Times gazetesinde yayınlanan "Turkey Loyal to Peace Front (Türkiye Barış Cephesine Sadık)" adlı haberde de görülmektedir: "Cumhurbaşkanı İnönü, Kral'ın özel mesajını getiren büyükelçiyi kabul etti. Kral mesajında, bu kaygı verici dönemde iki ülkeyi birbirine bağlayan güçlü ve dostane bağlardan duyduğu memnuniyeti belirtmektedir." Haberde ayrıca, İngiltere ve Fransa'nın Almanya ile savaşa girdiği haberinin Türkiye'de memnuniyetle karşılandığından, Türklerin dışarıda gezmektense, evde oturup, Londra'dan yapılan yayınları dinlediğinden ve Türklerin hayatın her alanında ister küçük, ister büyük olsun tüm ulusların özgürlüğünden yana olduklarından söz edilmektedir. Haberin sonunda ise, Türkiye'de bulunan Alman ve İtalyanlara hükümetlerince, Türkiye ile savaşa girilmesi durumunda Bulgaristan'a tahliye edileceklerinin bildirildiği vurgulanmaktadır. ${ }^{9}$

6 Eylül 1939 tarihli The Times gazetesinde "Watchfulness in Turkey / All Eyes Turned on Italy (Türkiye Pürdikkat / Tüm Gözler İtalya’ya Çevrildi)” başlıklı haberde, Kamutay'ın önceden kararlaştırılan tarihte toplanmasının nedeninin, Türkiye'nin durumunda bir değişiklik olmaması olduğu belirtildikten sonra, tüm gözlerin Türkiye'nin tarafsızlığının tarafsızlığına bağlı olduğu İtalya'ya çevrildiği ve İtalya'nın çatışmaya hemen girmemesinin, Türkiye'de tarafsız kalma kararı aldığı şeklinde yorumlandığı haber verilmektedir. ${ }^{10}$

Türkiye'nin İngiltere ve Fransa ile ayrı ayrı imzaladığı deklarasyonların oluşturduğu beklenti ise, 8 Eylül 1939 tarihli The Times gazetesinde yer alan "Turkish Sympathies with the Allies (Türklerin Müttefik Sempatisi)" adlı haberde açıçca görülmektedir: "Burada İngiltere ve Fransa'nın Almanya ile savaş halinde olduğuna ve Türkiye'nin eninde sonunda İngiltere ve Fransa ile olan taahhütleri nedeniyle savaşa gireceğine inanmak zor... Bununla birlikte, olayların gerektirmesi durumunda, ülkenin taahhütlerini yerine getirmek için sessiz ve kararlı bir şekilde hazırlandığı bilinmektedir." Ayrıca, diğer Balkan ülkelerinin barışçıl tutumlarını ve tarafsızlıklarını ilan etmelerine rağmen, Türkiye'den henüz resmi bir açıklama gelmediği de vurgulanmaktadır. ${ }^{11}$

Polonya'nın sonunun yakın olduğunu görünce Sovyetler de emperyalist emellerini gerçekleştirmek, firsattan faydalanmak ve 23 Ağustos Paktı'nın kendilerine ayırdığı parsayı ele geçirmek için harekete geçtiler. 17 Eylül sabahı Sovyet orduları da Polonya'ya girmeye başladı. Rusya'nın bu saldırganlığı karşısında İngiltere ve Fransa, Sovyet Rusya'ya da savaş ilan etmeyi

9 “Turkey Loyal to Peace Front”, The Times, 3 Eylül 1939, s. 7.

10 "Watchfulness in Turkey / All Eyes Turned on Italy", The Times, 6 Eylül 1939, s. 5.

11 "Turkish Sympathies with the Allies", The Times, 8 Eylül 1939, s. 7. 
İkinci Dünya Savaşındaki Mihver İlerleyişinin Türk Dış Politikasına Etkilerinin...

düşündülerse de, bu devleti Almanya'nın kucağına daha fazla itmek olacağından vazgeçtiler. 27 Eylül'de Varşova'nın teslim olmasıyla Polonya haritadan siliniyordu. ${ }^{12}$

Türkiye açısından Sovyetlerin bu hamlesi şüphesiz çok önemlidir. Bu önem 19 Eylül 1939 tarihli The Times gazetesinde çıkan "Turkey's Delicate Position (Türkiye'nin Nazik Durumu)" başlıklı haberde de görülmektedir: “...Bu arada, Polonya' ya gerçekleşen Rus saldırısına İngiltere ve Fransa'nın vereceği tepki Türkiye'de merakla beklenmektedir. Bu ülke, sadece Batılı iki devletle taahhütlere sahip olmayıp, aynı zamanda Rusya ile de en iyi şekilde geçinmek istemektedir. Türkiye, potansiyel saldırganların İtalya ve Almanya olacağ 1 varsayımına dayanarak ve Sovyetlerin de onayını alarak İngiltere ve Fransa ile anlaşma yapmıştır. Sovyetler Birliği'nin Avrupa'daki bozması ön görülmemiştir. Sonuç olarak Türkiye'nin durumu çok nazik bir hal alabilir."13

\section{Mihverin Ayak Sesleri}

\subsection{Türkiye ve Balkanlar}

İngilizler açısından Almanya ve Sovyetler Birliği'ne karşı Güneydoğu Avrupa'da Balkan devletlerinin oluşturacağı bir blok oldukça büyük önem taşıyordu. Bu sayede, Balkanlar'ın bu iki devletin kontrolüne alınması en azından daha güç hale gelecekti. Balkan devletlerinin önceliği ise, Almanya ve Sovyetler Birliği gibi hemen yanı başlarında bulunan iki büyük devlet ile iyi geçinmek ve böylelikle işgale uğrama tehlikesinden uzak durmaktı.

Mayıs 1939'da imzalanan Türk-İngiliz Ortak Deklarasyonu'nun Balkanlar ile ilgili ve Balkanlar'da güvenliğin sağlanmasına yönelik altıncı maddesi, Balkan devletleri tarafından tepki ile karşılanır. Yugoslavya ve Romanya deklarasyonun altıncı maddesini Mihver güçlerini Balkanlar'a saldırmaya kışkırtacağı gerekçesiyle protesto ederler. Saraçoğlu, Rumen Dışişleri Bakanı Gafencu'ya deklarasyonun altıncı maddesinin Balkanlar'daki sorunlarda yalnızca Türkiye ile İngiltere arasında gerçekleşecek bir danışma ile sınırlı olduğu yolunda güvence vererek, Balkan devletlerinin bu huzursuzluğunu gidermeye çalışır. Balkan Antantı'nda derin bir bölünme artık gözle görülür hale gelmişti. Tüm baskılara karşın, Yunanistan Türkiye'nin Batılı güçlerle yaptığı ittifakın yanında yer alan tek Balkan ülkesi olacaktır. ${ }^{14}$

Bulgaristan'ın Balkan Antantı'na katılmayacağı kesinlik kazandıktan sonra Türkiye, Bulgaristan ile gergin ilişkilerin yumuşatılmasını sağlamak üzere 13 Ocak 1940'da Türk-Bulgar Ortak Beyannamesi'ni kabul etmişti. Beyannamede, taraflar birbirlerinin tarafsızlıklarına saygı göstereceklerine karşı1ıklı olarak güvence veriyordu. Ayrıca, Türk-Bulgar sınırındaki askeri birlikler de karşıl1klı olarak geri çekilecekti. ${ }^{15}$

27 Ocak 1940'ta yayınlanan The Times gazetesi, Türk-Bulgar Ortak Beyannamesi'ni değerlendiren "Turco-Bulgarian Relations (Türk-Bulgar İlişkileri)" başlıklı bir habere yer vermiştir: "Türk-Bulgar ilişkileri Kasım ayından bu yana gelişme göstermektedir ve Türk Dışişleri Genel Sekreteri Menemencioğlu'nun Londra ve Paris ziyaretlerinden ülkesine geri

${ }^{12}$ Fahir Armaoğlu, 20. Yüzyıl Siyasi Tarihi, Alkım Yayınevi, İstanbul 2007, s. 361-362.

13 “Turkey's Delicate Position”, The Times, 19 Eylül 1939, s. 5.

${ }^{14}$ Koçak, age, s. 297.

15 Tuncer, age, s. 72. 
dönerken Sofya'ya gerçekleştirdiği ziyaret ortak güveni tesis için çok değerli bir temel oluşturmuştur. Menemencioğlu, Sofya'ya esas olarak, Bulgaristan'ın Türkiye'ye ve diğer komşularına olan tutumu ile ilgili olarak açık bir fikir elde etmek için ziyarette bulunmuştur. Bugünlerde "tarafsızlık" kelimesi, bir ülke ile diğer arasındaki ilişkileri tanımlamakta çok da aydınlatıcı bir kelime değildir. Menemencioğlu'nun Kral Boris ve Bulgaristan Başbakanı ve Dışişleri Bakanı olan Kiosseivanoff ile yaptığı görüşmeler tabloyu netleştirmiştir. Türk Hükümeti Bulgaristan'ın tarafsızlığına ve toprak bütünlüğüne saygı göstereceği yönünde teminat vermiştir. Bulgaristan Hükümeti de, hiçbir komşusuna karşı agresif niyetleri olmadığını ve hiçbir Güce, Türkiye'ye kuzeyden baskı oluşturmak amacıyla Bulgaristan'1 kullanma yönünde tolerans göstermeyeceğini açık bir şekilde ifade etmiştir. Bu dostane görüşmeleri ve teminatları iki Hükümet arasında daha yakın bir işbirliğinin takip etmesi umulmaktadır."16

"Self Help in the Balkans (Balkanlar'da Kendi Kendine Yardım)" başlığı ile 2 Şubat 1940'ta The Times'da yayınlanan haberde, Balkan Antantı üyeleri olan Türkiye, Romanya, Yunanistan ve Yugoslavya dışişleri bakanlarının bugün Belgrad'da toplanacağı haber verilmektedir. Ayrıca, gerçekleştirilen son görüşmelerin Balkan Antantı ile Bulgaristan ve Macaristan arasındaki gerilimi azalttığ yorumu da yapılmaktadır. ${ }^{17}$

Yine, Roma'dan bildirilen 2 Şubat tarihli "Italian Advice to Balkans (Balkanlar'a İtalyan Tavsiyesi)" başlıklı haber Balkan Antantı'na İtalya'nın verdiği tepkiyi gözlemlemek açısından ilgi çekicidir: " Yarınki toplantıya büyük önem verilmektedir ve çeşitli Balkan ülkesi devlet adamlarının ve resmi gazetelerin yaptığı açıklamalar İtalya'nın pozisyonu ile çelişiyor olarak değerlendirildi. Bir Balkan Bloğu oluşturmaya yönelik İtalya'nın düşmanca politikası bir kez daha teyit edildi çünkü bu politika tarafsızlık ve barışın korunması açısından en iyi şanstır. Balkan ülkeleri arasındaki sorunların çözülmesinin zaman alacağı ve bu nedenle Belgrad Konferansı'nın şaşırtıcı bir sonuç ortaya çıkarmayacă̆ı görülmektedir." Haberde ayrıca, İtalya'nın Arnavutluk ile birleşmesinden bu yana artık Yunanistan ve Yugoslavya ile sınırları olan bir Balkan devleti olduğunun ve Ege'deki İtalyan toprakları nedeniyle de Türkiye'nin de bir komşusu olduğunun bu ülkelere hatırlatıldığı bildirilmektedir. ${ }^{18}$

Almanya'nın 2 Şubatta başlayan toplantıya tepkisi, 3 Şubat tarihinde The Times gazetesinde "German Eyes on Belgrade (Almanların Gözü Belgrad'da)" başlığı ile verilmiştir: "Almanya, Belgrad'daki Balkan Antantı toplantısını gizlemeye çalıştığı karışık duygular içerisinde izlemektedir. Balkanları Lebensraum'unun (Yaşam Alanı) bir parçası olarak görmektedir ve bu nedenle, Balkan ülkelerinin bir araya gelmesini ve dış etkilere karşı onları daha iyi bir pozisyona getirecek bir anlaşmaya varmalarını hoş karşılamamaktadır. Bulgar iddialarını cesaretlendirerek aralarına nifak sokma çabalarını çeşitli olaylarla gösterdi ve ayrıca gıda kaynaklarına ve hammaddelerine ihtiyaç duyduğu Yugoslavya ve Romanya'ya da ilgi gösterdi. Konferans ilk duyurulduğunda, onu bozmak için çaba gösterdi ve bunun Ankara kaynaklı bir İngiliz-Fransız diplomasisi olduğu şeklinde saldırıda bulundu." 19

16 "Turco-Bulgarian Relations", The Times, 27 Ocak 1940, s. 5.

17 "Self Help in the Balkans", The Times, 02 Şubat 1940, s. 8.

18 "Italian Advice to Balkans", The Times, 02 Şubat 1940, s. 8.

19 "German Eyes on Belgrade", The Times, 03 Şubat 1940, s. 6. 
İkinci Dünya Savaşındaki Mihver İlerleyişinin Türk Dış Politikasına Etkilerinin...

2 Şubat 1940'da Belgrad'da yer alan Balkan Antantı'nın yıllık Bakanlar Konseyi toplantısına katılan Şükrü Saraçoğlu, Balkan ülkeleri yetkililerine ortak tehlike karşısında ortak karar ve tutum alma çağrısında bulunmuş, ancak diğer üye devletlerin isteksiz tutumları bu yolda bir karara alınmasını olanaksız kılmıştı. Türkiye, Balkanlarda Almanya’ya karşı bir güvenlik alanı oluşturma çabasında yalnız kalmıştı. Türkiye ile Batılı Güçler arasındaki yakınlaşma arttıkça, Balkan Antantı'nın çözülüşs süreci de hızlanmıştı. ${ }^{20}$

Balkan Antantı Konseyi toplantısının sonucunda Türkiye'de ortaya çıkan görüşler 6 Şubat 1939 tarihinde yayımlanan "First Impressions in Turkey (Türkiye'de İlk İzlenimler)" başlıklı haberde yer almaktadır: "Türklerin pozisyonu açısından Balkan Antantı Konseyi toplantısının sonuçları oldukça tatmin edicidir. Belgrad'da yayınlanan resmi açıklamadan çıkarılan sonuç, dört Balkan ülkesinin her birinin politikasının coğrafi konumu tarafından belirleneceğidir. Bu nedenle, Yugoslavya ve Romanya kuzey komşuları ile mümkün olduğunca iyi ilişkiler sürdürmeye çalışırken, Türkiye, İngiltere ve Fransa'ya olan taahhütlerine sadık kalacak ve Yunanistan'da bu zorlu sularda dikkatli yol alacaktır. Açıklamanın satır araları okunduğunda, söz konusu ülkelerin, ne zaman gelirse gelsin, aralarından herhangi birine bir saldırı olduğunda, bunun diğerleri için de tehlikeli olacağını ve ortak savunma için birleşmeleri gerektiğini anladıkları izlenimini vermektedir. Bu durumu, Belgrad' da ima etmekten öteye geçememelerinin nedenleri şunlardır: En büyük üç askeri güç şu anda Avrupa'da savaş halindedir; En büyük Beş Gücün diplomasileri Balkanlar' da yoğun biçimde aktif durumdadır; geçen yıl, Balkanlar ile ortak sınırı olan iki Güç, İtalya ve Sovyetler Birliği, Balkan Antantı'na olan tavırlarını değiştirdiler; birisi dostluktan düşmanlığa, diğeri de düşmanlıktan dostluğa geçiş yaptı. Bu şartlar altında, Antant'ın sadece ayakta kalmayıp, aynı zamanda Belgrad'da alınanlar gibi kararlar alması neredeyse mucizedir. Bulgaristan'ın komşularıyla, özellikle de Türkiye'yle ilişkilerini geliştirmesi, bu ülkede memnuniyetle karşılanmaktadır." ${ }^{\text {"1 }}$

\subsection{Fransa'nın Yenilgisi}

10 Mayıs 1940 tarihi 2. Dünya Savaşı açısından iki önemli olaya tanık olmuştur. Bunlardan birincisi İngiltere'de Chamberlain'in yerine Winston Churchill'in başbakanlığa gelişi, ikincisi ise Almanya'nın Batı Taarruzu'na başlamasıdır. 10 Mayıs'ta Batı Cephesi savaşının başlamasından sadece 5 gün sonra, 14 Mayıs'ta Hollanda teslim oldu. 27 Mayıs'ta Belçika Kralı teslim olmak zorunda kaldı. Belçika ve Hollanda'nın yardımına koşan İngiliz kuvvetleri ise keskin bir Alman manevrasıyla Fransızlardan ayırtılarak Dunkerque'e doğru sıkıştırılıyorlardı. 19 Mayıs'ta Almanlar Birinci Dünya Savaşı'nın ünlü savaş alanı olan Somme'a ulaştılar. Zaten daha 16 Mayıs'ta Fransızların Sedan hattı çökmüştü. 23 Mayıs'ta Fransa'nın en çok güvendiği Maginot istihkam hatları Schel'de yarıld1. ${ }^{22}$

Almanya'nın Fransa'ya saldırısı Türkiye'de de yakından takip edilmiştir. Bu konu ile ilgili 21 May1s 1940 tarihli The Times gazetesinde "Turkey Stands by Her Friends (Türkiye Dostlarının Yanında)” başlıklı haberde şunlara yer verilmişti: “...Mevcut savaşın Balkanların kaderini de tayin edebileceğinin farkında olan Türk basını Batı Cephesi'nden gelen haberleri

20 Tuncer, age, s. 72.

21 "First Impressions in Turkey", The Times, 06 Şubat 1940, s. 7.

22 Şevket Süreyya Aydemir, Íkinci Adam, Remzi Kitabevi, İstanbul 1985, s. 151. 
dikkatle takip etmektedir. Bununla birlikte, yorumcular Alman ilerlemesinin hizından şaşırmamış görünmektedir. İlk Alman başarılarının beklendiği ancak saldırının getirdiği avantajların yok olacağı ve Müttefiklerin etkili bir şekilde karşı saldırıya geçecekleri zamanın geleceği görüşünü paylaşmaktadırlar. Müttefiklerin nihai zaferi tüm gazetelerde belirtilmektedir." ${ }^{23} \mathrm{Bu}$ haberde de görüldüğü üzere, Alman saldırılarının başarısına ve hızına rağmen, İngilizler hala umutlarını korumakta ve Üçlü İttifak ile kendi yanlarında savaşın içine çekmeye çalıştıkları Türkiye'nin umudunu da canlı tutmaya çalışmaktadırlar.

24 Mayıs 1940 tarihli The Times'da ise, Türk kamuoyunun yeni göreve gelen İngiliz ve Fransız hükümetlerine olan güveninden söz edilen "Turkey Remains Calm (Türkiye Sakinliğini Koruyor)" başlıklı haber göze çarpmaktadır: “...Askeri uzmanlar, başlangıçtaki Alman başarılarını ilk olarak İngiltere'nin geç müdahalesine, ikinci olarak da, Fransızların tankın potansiyelini görememelerine bağlamaktadırlar. Bir önceki savaşta tankın geliştirilmesinde büyük rol oynayan Churchill'in ve tankın potansiyelini generallerden daha iyi gören Reynaud'un İngiliz ve Fransız hükümetlerinde göreve gelmeleriyle birlikte, mekanizasyondaki eksikliklerin giderilmesi çabalarının boşa gitmeyeceğine inanılmaktadır..."24 Bu haberde göze çarpan nokta, İngilizlerin Almanya'nın Yıldırım Savaşı'nın belkemiğini oluşturan mekanize birliklerin, özellikle de tankın, önemini kavramış olduklarıdır. Bunu, Türk askeri otoritelerinin ağzından aktarmaları ise ironik bir durumdur.

Alman kuvvetleri zafer coşkunluğu ile Fransa'nın içine dalgalar halinde daldılar. Çok kalabalıktılar ve çok hızlı gidiyorlardı. Fransız Hükümeti, 10 Haziran'da Paris'ten alelacele ayrıldı ve General von Kuechler'in 18. Ordusu 14 Haziran'da Fransa'nın gözbebeği olan savunmasız büyük şehre girdi. Eiffel Kulesi'ne hemen gamalı haç bayrağı çekildi. Bordeaux'a kaçan hükümetin başbakanı Reynaud 16 Haziran'da istifa etti. Yerine Petain geçti. Petain ertesi gün İspanya elçisinin aracılığıyla Almanlardan ateşkes antlaşmasını imzalamasını istedi. ${ }^{25}$

Ateşkes Antlaşması 22 Haziran 1940 akşamı, Fransızların 1. Dünya Savaşı sonunda, 11 Kasım 1918'de, Almanlara mütareke antlaşmasını imzalattıkları vagon içerisinde, yine aynı noktada, Compiegne'de, imzaland.

“Turkey Anxious but Calm (Türkiye Kaygılı Ancak Sakin)” başlıklı 19 Haziran 1940 haberi, Fransa'nın yenilgisinin Türkiye'de uyandırdığı duygu ve düşünceleri yansıtması bakımından önemlidir: "Türkiye, Batı' daki olayları kaygılı ancak sakin bir şekilde beklemektedir. Bu ülke, Fransa Savaşı'nda Fransa'nın yenilgisine hazırlıklıydı ancak Fransa'nın silahlarını bırakma ihtimaline hazırlıklı değillerdi çünkü savaşa İmparatorluk üslerinden ve İngiltere'den devam edilebilirdi. Mareşal Petain'in açılaması, birkaç gün önce Reynaud tarafindan yapılan ile karşılaştırılmaktadır. Türkiye'nin, Müttefiklerin zaferine olan güveni, Reynaud'un verdiği teminatlara bağlıydı ki, bunlar artık mevcut olaylarla çürütülmüştür. Bununla birlikte, İngilizlerin savaşmaya devam etme kararlılıklarına hala güvenilmektedir. Türkiye, Fransa'nın teslim olması durumunda Suriye'nin statüsü hakkında kaygılıdır. Alman Büyükelçisi Papen'in İtalya'nın

23 "Turkey Stands by Her Friends", The Times, 21 Mayis 1940, s. 6.

24 “Turkey Remains Calm", The Times, 24 Mayıs 1940, s. 5.

${ }^{25}$ Shirer, age, s. 934. 
İkinci Dünya Savaşındaki Mihver İlerleyişinin Türk Dış Politikasına Etkilerinin...

Suriye'ye karşı harekete geçmeyeceğine dair Türk Hükümetine teminat verdiği anlaşılmaktadır." 26

Fransızların uğradığı felaket Türkiye için derin bir şok oldu. Avrupa savaşında yer almama inançları bir kez daha teyit edilmişti. Türkler, Fransızların Avrupa'daki en iyi orduya sahip olduğunu düşünüyordu. İnönü'nün kendisi de, Batı'daki savaşın Maginot hattında geçeceğini ve dört, beş yıl süreceğini düşünüyordu. İngilizler de savaşın uzun süreceğini düşünüyordu. Fransızlar birkaç hafta içerisinde yenilince, Türkler şok, öfke ve korkudan oluşan bir tepki verdiler çünkü Fransa kendi sonunun yaklaştığını bildiği halde Türkiye'ye sorumsuz bir şekilde savaşa girme baskısı yapmışlardı. Türklerde aynı zamanda bir rahatlama duygusu vardı çünkü tedbirli politikalarının işe yaradığını görmüşlerdi ve Türk çıkarlarını ilk plana koyan gerçekçilikleri ve pragmatiklikleri yaşanan olaylarla desteklenmişti. ${ }^{27}$

\section{3. İtalya'nın Savaşa Girişi}

22 Mayıs 1939 tarihinde Almanya ile imzaladığı Çelik Pakt ile yaklaşmakta olan savaşta yer alacağı tarafi beyan eden İtalya'nın, 2. Dünya Savaşı'nın başladığı günden itibaren ne zaman savaşa gireceği dünya kamuoyunda ve siyasi çevrelerde sürekli merak konusu olmuştur. $\mathrm{Bu}$ merak temelsiz değildi çünkü İtalya Habeşistan ve Arnavutluk işgalleri ile niyetini belli etmiş, Çelik Pakt'ı imzalayarak da bu niyetini mühürlemiştir. Bu gelişmelere rağmen, İtalya'nın savaşın hemen başında Almanya ile birlikte savaşa girmemesi ise Mussolini'nin Almanya'nın gerçek gücünü göstermesini bekleyip, görme stratejisinin sonucudur. Almanya'nın Fransa'ya saldırısı ve yıllarca sürmesi beklenen savaşın birkaç hafta içerisinde Almanya lehine hızla gelişmesi Mussolini'nin beklediği cevaptı. Olayların bu şekilde seyri, 1940 Haziran'ına gelindiğinde İtalya'nın savaşa girmesini an meselesi haline getirmiştir.

4 Haziran 1940 tarihli The Times gazetesinde "French Commander's Visit to Angora (Fransız Komutanın Ankara Ziyareti)" başlıklı haberin satır aralarında İtalya'nın niyetinin ilk ipuçları okunmaktadır: “...Türkiye, Sinyor Mussolini’nin yarın söyleyebileceklerini veya yapabileceklerini sakin bir şekilde beklemektedir. Hem Türk hem de Yunan Hükümetleri bugün, İtalya'nın, Fransa ve İngiltere baskısı altında Türk askerlerinin Doğu Ege'deki Yunan adalarını işgal etmesinin önceden planlandığı yönündeki iddialarını yalanladı. İtalya'nın bu açıklaması, İtalyan sözcünün İngiliz ve Fransız topraklarına bir saldırı planlandığı şeklindeki beyanına rağmen, İtalya'nın Yunanistan'1 ele geçirebilmesi için bir sebep üretme çabası olabilir."28

The Times'ın Ankara muhabirinin bir sonraki gün geçtiği "Turkey and Rome Assurances (Türkiye ve Roma Teminatları)" başlıklı haber, Türkiye'nin 2. Dünya Savaşı öncesinde ve başlangıcında en çok çekindiği durumun, yani İtalya'nın savaşa girmesinin, artık an meselesi olduğunu göstermektedir: "Roma'dan gelen raporlara göre, İtalya'nın Akdeniz'de yapacağı herhangi bir harekat ile birlikte Türkiye'ye kendisine karşı hiçbir agresif hareketin planlanmadığı güvencesi verilecektir. Türk hükümeti bu türden teminatları, geçen yılın Mayıs ayında İngiltere, Fransa ve Türkiye tarafindan yapılan deklarasyonlar sonrasında Almanya ve İtalya'dan da

26 “Turkey Anxious but Calm", The Times, 19 Haziran 1940, s. 5.

${ }^{27}$ Selim Deringil, "The preservation of Turkey's neutrality during the Second World War: 1940", Middle Eastern Studies, Vol.18, 1982, s. 30-52.

28 "French Commander's Visit to Angora", The Times, 04 Haziran 1940, s. 5. 
almıştı. Bununla birlikte, İngiltere ve Fransa ile ittifak antlaşmasını sonlandırmak için çalıştılar çünkü bunu, Türk bağımsızlığı ve çıkarları açısından Mihver Güçlerinin verdiklerine göre daha etkili bir koruma olarak değerlendirdiler. O zamandan bu yana Mihver teminatlarının değeri giderek düşmeye başladı. Türkiye'nin, İtalya'nın Akdeniz'deki herhangi bir hareketine karşılık vereceği tepki, böyle bir duruma karşı İngiltere ve Fransa'ya taahhüt ettiği gereklilikler uyarınca ve, Türk ve Müttefik yetkililerce son aylarda yapılan sık görüşmelerde ele alınmış olabilecek anlaşmalar çerçevesinde sorumluluklarını yerine getirmek olacaktır." ${ }^{29}$ Hükümetlerin, gazetelerin ağzından yarı resmi açılamalar yapabildiği gerçeği göz önüne alındığında, Türkiye'nin savaşa girme sorumluluğu olduğunun ima edilmesi, Fransa'nın hızla kaçınılmaz yenilgisine doğru gittiği bu dönemde Türk tarafında derin hayal kırıklığı yaratmıştır.

11 Haziran 1940'ta İtalya Müttefiklere savaş ilan etti. Bu gelişme Türkiye'nin İngiltere ile imzalamış olduğu antlaşmanın 1.Maddesi gereğince savaşa katılması demekti. Zira savaş Akdeniz'e gelmişti. Ama Türk tarafı çok önceden alınmış bir karar uyarınca böyle bir yükümlülüğe işlerlik kazandırmama çabasına girişti. ${ }^{30}$

İtalya'nın savaşa girmesi 11 Haziran 1940 tarihli The Times Gazetesi'nde "Mussolini Enters the War (Mussolini Savaşa Girdi)” başlığı ile verilmiştir: “ Mussolini dün akşam Roma'da, İtalya'yı dört bir yandan sarmalayan plütokrasiler olan İngiltere ve Fransa'ya savaş ilan ettiğini açıkladı. Mussolini, İtalya'nın komşu ülkeleri savaşa sürüklemek istemediğini ve İsviçre, Yugoslavya, Türkiye, Misır ve Yunanistan'a bu teminata güvenmelerini söyledi ve bunun gerçekleşmesinin kendilerine bağlı olduğu şeklinde uyarıda bulundu..."31

Volume 12

Issue 5

October

2020

Türkiye'nin savaş dışı kalma tutumu ise 17 Haziran 1940 tarihli The Times gazetesinde "Turkey's Watch on Events (Türkiye Olayları Takip Ediyor)" başlıklı haberde yer almaktadır: "Müttefik büyükelçileri ile Türk Dışişleri bakanı arasındaki ilk temaslar bugün devam etti. Olayların gelişimi daha fazla müzakereyi gerekli kılmazsa, Türkiye'nin pozisyonunu netleştirecek bir açıklamanın yarın yapılması bekleniyor. Görünen o ki, Türkiye şu anda savaş dışı kalma tutumunu değiştirmeyecek. Aynı zamanda, Cuma günü yapılan Halk Partisi toplantısından sonra yayınlanan açıklamanın önemi, Türkiye'nin ittifakından ayrılmayacağıdır. Bununla birlikte, hareketleri Fransa'daki durumdan, Sovyetler Birliği’nin gizemli tavırlarından ve Türkiye'nin halihazırdaki hazırlık durumundan etkilenmektedir. ${ }^{32}$

Sonuç olarak, Türk-İngiliz-Fransız Üçlü İttifakı'nın Ek 2 No'lu protokolü uyarınca, Türkiye savaş dışı tutumunu sürdürmeye devam etmiş ve 22 Haziran'da Fransa'nın Almanya ile mütareke imzalamasıyla da Müttefiklerin Türkiye'nin savaşa girmesi yönündeki baskıları geçici bir süreyle de olsa azalmıştır.

\section{4. İtalya'nın Yunanistan'a Saldırısı}

İtalya, Almanya'ya haber bile vermeden ve İtalyan genelkurmayının muhalefetine rağmen, 28 Ekim 1940 sabahı saat 2'de Yunan hükümetine verdiği bir ultimatomda, Korfu ve Girit adaları

\footnotetext{
29 "Turkey and Rome Assurances", The Times, 05 Haziran 1940, s. 5.

${ }^{30}$ Deringil, age, s. 115.

31 "Mussolini Enters the War", The Times, 11 Haziran 1940, s. 6.

32 "Turkey's Watch on Events", The Times, 17 Haziran 1940, s. 6.
} 
İkinci Dünya Savaşındaki Mihver İlerleyişinin Türk Dış Politikasına Etkilerinin...

ile Epir ve Pire limanlarının kendisine teslimini istedi. Bu istek için ileri sürülen sebep, Yunanistan'ın İngiltere'ye üs vermesiydi. Yunanistan, İtalya'nın bu isteklerini hemen reddedince saat 5.30'dan itibaren Arnavutluk'ta toplanan İtalyan kuvvetleri Yunan sınırından içeri girmeye başladi. ${ }^{33}$

İtalya'nın Yunanistan'a saldırısının Türkiye'de yarattığı etki, 30 Ekim 1940 tarihli "When Turkey Will Move (Türkiye Ne Zaman Harekete Geçecek)" haberde açıklanmaktadır: "Şu ana kadar İtalya'nın Yunanistan'a saldırısı ile ilgili Türkiye'nin resmi tepkisi açıklanmadı. Bununla birlikte, iyi haber alan çevrelerde duyulanlara göre, Türkiye'nin savaş dışı tutumunu, söz konusu savaşta sadece İtalya'nın bulunduğu sürece devam ettireceği ancak Bulgaristan'ın harekete geçmesi durumunda Türkiye'nin, Yunanistan'ın yardımına askeri kuvvetleri ile gideceği yönündedir. Almanya'nın Yunanistan'a saldırısı hiçbir Türk-Yunan anlaşmasında yer almamaktadır ancak Ankara'da Almanya'nın yeterince askere sahip olmadığına ve Balkanlar'da daha fazla askeri operasyona girebilecek kadar Romanya'da durumunu konsolide etmediğine inanılmaktadır..."34

İtalyan-Yunan çatışmasının ilk günlerinde 8 Kasım 1940'ta The Times'da “Turks on Greek Resistance (Yunan Direnişine Türk Bakışı)" başlığı ile çıkan haber, Türkiye'de bu çatışma ile ilgili oluşan havayı yansıtması ve aynı zamanda Türkiye için ufukta yavaş yavaş belirmeye başlayan Alman tehdidinin ilk sinyallerini vermesi bakımından önemlidir: "Türkiye, Yunan Ordusu'nun İtalyanlara verdiği cevaptan gerçekten memnuniyet duymaktadır. Her yüzde bir gülümseme var. İngiliz askerlerine karşı alınacak bir yenilgi, İtalyan askeri prestijine bu kadar zarar veremezdi ancak Yunanistan gibi küçük bir devlet karşısında alınan yenilgi, İtalyanların dünyanın bu bölgesinde komik duruma düşmesine neden oldu. Türk askeri uzmanlar ise, olanlar karşısında şaşırmadı. Arnavutluk-Yunanistan sınırındaki coğrafyayı iyi biliyorlar. Ayrıca, Yunanların tahrik edildiklerinde yılmaz savaşçılar olduklarını ve İtalyanların da savaşa yüreklerini koymadıklarını biliyorlar. Mussolini’nin kendini bu riskli duruma neden soktuğu sorusu kafalarını karıştırıyor ve bunun, yanlış bilgilendirmeden kaynaklanan bir hata olduğu sonucuna variyorlar..."35

21 Kasım 1940 tarihli The Times'da yer alan "If Bulgaria Attacks Greece (Bulgaristan Yunanistan'a Saldırırsa)" başlıklı haberde ise, Türkiye'nin, Bulgaristan'ın Yunanistan'a saldırması durumunda vereceği yanıtın ne olacağının cevabı görülmektedir: "Kral Boris'in, Berchtesgaden'e yaptığı ziyaret Ankara'da huzursuzluğa yol açtı. Ziyaretin yapılması dışında çok az bilgi bulunmaktadır. Türkiye'yi ilgilendiren soru, Kral'ın, Berchtesgaden'e sözde “yeni düzen" ile ilgili soruları tartışmak için mi yoksa Balkanlar'da Yunanlara karşı İtalyan'lara yardım etmek üzere bir harekat amacıyla yapılacak Alman hazırlıkları için mi gittiği yönündedir. Aynı durum, Macar Bakanlar'ın Viyana ziyareti için de geçerlidir. Türkler, Almanya'nın, Bulgaristan üzerinden Yunanistan'1 işgal etmek için veya Bulgaristan'ın, Yunanistan'a saldırması durumunda onu etkili bir şekilde desteklemek üzere yeterli askere sahip olmadığını düşünmektedir. Türklerin düşüncesi, Kral Boris, Berchtesgaden'e gidene kadar, Bulgaristan'ın

\footnotetext{
${ }^{33}$ Armaoğlu, age, s. 370.

34 "When Turkey Will Move", The Times, 30 Ekim 1940, s. 4.

35 "Turks on Greek Resistance", The Times, 08 Kasim 1940, s. 4.
} 
harekete geçmeyeceği şeklindeydi. Şimdi durum bu kadar kesin değil. Bununla birlikte, siyasi çevrelerde Türkiye'nin kararını verdiği ve kişiliğini ortaya koyduğu belirtilmektedir. Bulgaristan, Yunanistan'a saldırırsa, Türkiye harekete geçecektir."36

İtalya'nın ilk saldırıları ağır kayıpla püskürtülmüş, Yunanlar hemen karşı saldırıya geçerek kuzeydeki Makedonya bölgesinden Arnavutluk'a girmişler, 22 Kasım'da Görice'yi ele geçirmişlerdi. İtalyanlar ilk atılımda çok ilerlemiş oldukları kıyı bölgesinde de hızla geri çekilmek zorunda kalmışlardı. General Pagagos komutasındaki Yunan ordusu dağ savaşında üstün bir beceri göstermişti. Yıl sonunda bu ordu İtalyanları bütün cephede Arnavutluk'tan otuz mil geriye atabilmişti. On altı Yunan tümeni yirmi yedi İtalyan tümenini Arnavutluk’ta aylarca yerinden kımıldanamaz bir duruma sokmuştu. ${ }^{37}$

27 Kasım'da The Times gazetesinde yayınlanan “Turkish Service to Greece (Yunanistan'a Türk Hizmeti)" başlıklı haberde, Türkiye'nin Yunan-İtalyan çatışmasında Yunanistan başarısına dolaylı yoldan yaptığı yardım açıkça görülmektedir: “...Türkler başından beri İtalya'ya karşı Yunanistan'1 tutuyordu ancak Yunan başarısı en iyimser tahminlerinin bile ötesine geçti. Türkiye bu başarıya, Yunanistan'ın arkasını koruyarak katkıda bulundu. Türkiye sayesinde Yunan komutası Bulgaristan sınırındaki tüm askerlerini Arnavutluk'ta savaşmak üzere geri çekti. Bugün için Yunan-Bulgar sınırında tek bir jandarmanı bile bulunmadığı rahatlıkla söylenebilir. Ankara'da, Almanya'nın çatışmaya dahil olmayacağı yönünde bir izlenim giderek güçlenmektedir ve ayrıca, bunun en azından kısmen Türkiye'nin Trakya'da oluşturduğu güçlü hattan kaynaklandığı düşünülmektedir." 38

Volume 12

Issue 5

October

2020

\section{Mihver Kıskacında Türkiye}

\subsection{Almanya'nın Yunanistan'ı İşgali}

İngiliz takviye kuvvetlerinin Selanik'e birlik çıkarmalarının ardından, Almanya 1941'in Nisan ayında Yunanistan'ı işgal etti. Bu sırada Yunan ordusu asıl olarak Alman birliklerinin Bulgaristan'dan Yunanistan'a gireceği dağ geçitlerini tutmuştu. Oysa, Alman mekanize birlikleri Vardar Ovası üzerinden Yugoslavya'ya girmişlerdi. Bu şekilde Yunan ve Yugoslavya Ordularının meydana getirdiği müşterek cepheyi yararak Vardar üzerinden Selanik’e inmişti. Böylece büyük bir kısmı Trakya'da mevzilendirilmiş olan Yunan Ordusu'nun irtibatını kesmişlerdi. Almanya'nın ordular arasındaki irtibat kesmeye yönelik hızlı saldırısı sonucu Yunanistan'daki İngiliz ve Müttefik kuvvetlerinin çok büyük bir bölümü denizden Girit Adası'na tahliye edildi. ${ }^{39}$

Alman Ordusu'nun Yugoslavya ve Yunanistan'a yönelik saldırılarının Türkiye'de oluşturduğu tepkiler, 7 Nisan 1941 tarihli The Times'da "Turkey on Guard (Türkiye Savunmada)" verilmektedir: "Türk Kabinesi bu öğleden sonra toplandı. Bu toplantıdan sonra resmi bir açıklama yapılabilir. Bu yeni Alman saldırısına karşı Türk tepkisi "kaygılı" olarak

\footnotetext{
36 "If Bulgaria Attacks Greece", The Times, 21 Kasim 1940, s. 3.

${ }^{37}$ Winston Churchill, 2. Dünya Savaşı Hatıraları, Tek Başımıza Mücadele 1940, Çev: Mehmet Ali Yalkın, Örgün Yayınevi, İstanbul 2005, s. 345-346.

38 "Turkish Service to Greece", The Times, 27 Kasım 1940, s. 4

${ }^{39}$ Liddell Hart, II. Dünya Savaşı Tarihi Cilt I, Çev: Kerim Bağrıçık, Yapı Kredi Yayınları, İstanbul 2000, s. 144.
} 
İkinci Dünya Savaşındaki Mihver İlerleyişinin Türk Dış Politikasına Etkilerinin...

tanımlanabilir ancak çok da fazla şaşırma içermemektedir. Almanya'nın Yunanistan ve Yugoslavya saldırılarının beklenmesine rağmen, savaşın Türkiye'nin eşiğine ulaşması onu kayıtsız bırakmamaktadır. Bulgar tepkisi burada büyük bir dikkatle izlenmektedir. Türkiye halihazırda tedbirler almış durumda; bu tedbirler şimdi daha da artırılabilir ve genel seferberlik düşüncesi de göz ardı edilmemektedir. İngiliz, Yunan ve Yugoslav elçileri Dışişleri Bakanı Saraçoğlu tarafından sırasıyla kabul edildi. Bu görüşmelerde Alman saldırısı hakkında daha fazla resmi açıklamanın yapılmadığı anlaşılmaktadır çünkü Yugoslav Elçisi’nin Hükümeti ile olan iletişimi tamamen koptu." ${ }^{40}$

Almanya 6 Nisan 1941'de Yunanistan'a ve Yugoslavya'ya saldırdı. Yunanistan'in uğradığ yıkım Türkiye'nin en büyük kaygısının gerçekleşmesi demekti. Türkiye'nin kapı komşusu bir ülke yetersiz İngiliz desteği sonucu Almanya'nın askeri üstünlüğü karşısında eziliyordu. İngiltere'nin zayıflığı, kayg1 ve kırgınlığı kamçılarken, Yunanistan örneği İngiliz baskısına direnen Türk devlet adamlarını haklı çıkarıyordu. ${ }^{41}$

Savaşın Türkiye'nin sınırına dayanmasının yarattığı hava ve alınan tedbirlerden bazıları, 14 Nisan 1941 tarihli "Precautions in İstanbul (İstanbul'da Alınan Tedbirler)" başlıklı haberde anlatılmaktadır: "İstanbul bu hafta sonu depresyonun dibine vurdu. Tabi ki, bu şehir çok hızlı değişen bir şehir ancak Türk kamuoyunun düşüncesini daha açık temsil eden diğer merkezlerde de bir cesaret kırılması hissini gösteren kanıtlar var. Bu belki de şaşırtıcı değildir çünkü İstanbul'un gönüllü şekilde boşaltılması yönündeki çağrı ki, bu savaşın yakın olduğunu göstermektedir, Almanya'nın Balkanlar'da ve Afrika'daki başarılarına tesadüf etmektedir. Bu durum, Alman ordusunun yenilmez olduğu şeklindeki Alman propagandası tarafından kullanılmaktadır. Gazeteler kamuoyuna olayları kendi bağlamında görmelerini tavsiye etmektedir. Türkiye'nin, topraklarına saldırılmaması durumunda savaşa girmesinin ihtimal dahilinde olmadığı ancak sınırlarındaki askeri gelişmeler göz önüne alındığında tahliyenin mantıklı bir tedbir olduğu belirtilmektedir. Genel olarak askeri durum bakımından ise, kamuoyuna, Yunanistan'ın hala yenilmediği ve kahramanca direnişi nedeniyle Almanya'dan daha fazla tebrik edilmesi gerektiği hatırlatılmaktadır...Hükümet'in, İstanbul sakinlerinin belirli bölümlerine Anadolu'ya bedava ulaşım imkanı sunması, 24 saat içerisinde 30 bin başvuru aldı. Başvuruların 100 bin kişiyi kapsaması bekleniyor ancak bunların tamamı İstanbul'u hemen terk etmek istemiyor. Birkaç banka ve işyeri, merkezlerini İstanbul'dan taşımayı düşünüyor ve büyük İngiliz kolonisinin bu şehirde çok zorunlu işi olmayan üyeleri de ayrılabilir. Hükümet, yangın bombaları sonucu yaşam kaybını azaltmak için İstanbul'un ahşap evlerinde oturanları da tahliye etme kararı aldı. Almanya'nın Yugoslavya'ya saldırısından Basın'ın çıkardığı sonuç, Nazi Almanya'sının özgürlüğe ve diğer her ülkenin varlığına karşı bir tehdit olduğudur. Ünlü gazeteci Hüseyin Yalçın, Amerika ve Sovyetler Birliği'ne, savaşacak diğerleri hala varken silaha sarılmalarını tavsiye etmektedir." ${ }^{42}$

19 Nisan 1941 tarihli "Nazi Designs on Turkey (Türkiye Üzerine Nazi Tasarıları)" başlıklı haberde, Yunanistan'ın Nazi işgalinde olduğu artık kabul ediliyor görünmektedir. Haberde,

40 "Turkey on Guard", The Times, 07 Nisan 1941, s. 4.

${ }^{41}$ Deringil, age, s. 142.

42 "Precautions in İstanbul", The Times, 14 Nisan 1941, s. 3. 
Türkiye'yi ilgilendiren ilginç gelişmeler de yer almaktadır. Bu bilgiler yakın zamanda gerçekleşecek olayların habercisi gibidir: “Alman Büyükelçisi Papen dün Ankara'dan İstanbul'a hareket etti ve bugün de, buradan Almanya'dan gönderilen özel bir uçak ile Berlin'e Ribbentrop ile görüşmek üzere uçtu. Moskova'daki Alman Büyükelçisi Schulenburg'un da Berlin'e gittiği rapor ediliyor. Doğal olarak Papen'in ziyaretinin sonucu büyük bir ilgi ile bekleniyor ancak Ankara'da tam bir sakinlik söz konusu. Basın'da ve her türlü seviyeden yaptığımız görüşmelerde, tehlikenin yakınlaşmasının Türklerin bağımsızlıklarını ve topraklarını savunma azminde en küçük bir zayıflamaya yol açmadığı görülmektedir. Bu arada, Almanya, Balkan politikasını Rus hassasiyetlerine rağmen sürdürmektedir. Alman propagandasına göre, Sovyetler Birliği fait accompli'yi (oldu bitti) kabul etmeye ve Üç Güçlü ittifak sisteminde yerini almaya razı oldu. Buna göre, Almanya'nın Boğazları kontrolüne karşı Sovyetler Birliği'ne Basra Körfezi’nde bir yer verilecektir. Bu böyle olabilir. Türkiye açısından ise, Yunanistan' da hala direniş varken ve diplomatik baskı yapabilecek Alman kuvvetleri yok iken, Almanya ile ilişkilerinde bir kriz beklenmemektedir. Bu durumun ne kadar devam edeceği ise belirsiz ancak Türkler, sinırlı İngiliz yardımı ile Yunanların Alman ve İtalyan kuvvetlerini çok uzun süre tutamayacağını düşünmektedirler..." ${ }^{43}$

Yunanistan ve Yugoslavya'nın işgalinin tamamlanmasından sonra İngiltere'den Türkiye'ye yönelik olarak yapılan eleştirilere Türkiye'den verilen yanıtlar ise 1 Mayıs 1941 tarihli The Times'da "Explanations in Turkey" başlıklı haberde açıklanmaktadır: "Churchill'in konuşmasında Yunan Savaşı'na yapılan referanslar ile ilgili Türklerin yorumu tamamen olumlu değil. Churchill'in, Türkiye'nin Yugoslavya ve Yunanistan ile birlikte hareket etmemek suretiyle Balkanlar'daki yenilgiden kısmen sorumlu olduğunu ima etmesinin haksızlık olduğu düşünülmektedir. Bulgaristan'ın henüz Almanya tarafından işgal edilmediği ve Balkan yarımadasının ortak şekilde savunulmasının hala uygulanabilir olduğu dönemde Türkiye'nin Yugoslavya'ya açık bir ittifak önerdiği hatırlatılmaktadır. Yugoslavlar tamamen hazırlıksız yakalandılar ve iki hafta içerisinde savaş dışı kaldılar. Türkiye ordusunu hareket ettirseydi, Bulgaristan orduları karşısında belki küçük ilerlemeler kaydedebilirdi ancak Balkanlar'daki Alman kuvvetlerinin ağırlığını Türkiye'nin üzerinde hissetmesi uzun sürmezdi. Türk görüşüne göre, elde edilecek tek sonuç, Yugoslavya veya Yunanistan'dan ziyade Almanlara karşı durabilecek pozisyonu tehlikeye atmak olacaktı. Eldeki tüm İngiliz yardımı Yunanistan'a gitmişti ve bu, değerli olmasına rağmen, Yunan ızdırabını uzatmaktan başka bir işe yaramadı. Doğal olarak, Türkiye'nin Yunanistan ve Yugoslavya ile dayanışmasını bir şekilde göstermesinin Yugoslavya'nın seferberliğini tamamlayacak kadar Alman saldırısını geciktirip geciktiremeyeceği sorusu akıllara gelmektedir. Bu soru ile ilgili farklı görüşler vardır. Türkler, en muhtemel sonucun, ilk Alman saldırısının Yunanistan ve Yugoslavya'dan Türkiye'ye sapması olacağını düşünmektedir." Bu noktada ise, Türkiye'den İngiltere'ye yönelik eleştiriler haberde aktarılmaktadır: "Türkiye veya herhangi bir Balkan ülkesinin tavrı ile ilgili eleştiriler, İngiltere'nin Orta Doğu'ya neden daha fazla asker göndermediği sorusunu da beraberinde getirmektedir. İngiltere'nin kendi ülkesinde 3 milyon askeri silah altına aldığı belirtilmektedir. $\mathrm{O}$ zaman, neden İngiltere Yunanistan'a sadece üç veya dört bölük gönderebildi ve bunu da, Mısır'ın

43 “Nazi Designs on Turkey”, The Times, 19 Nisan 1941, s. 4. 
İkinci Dünya Savaşındaki Mihver İlerleyişinin Türk Dış Politikasına Etkilerinin...

savunmasını tehlikeye atarak yaptı." Türk basınındaki kalemlerin savaş öncesinde ve savaş sırasında savaşan taraflardan hangisinin yanında yer aldığını gösteren belirgin bir örneğe haberin kalan kısmında şahit olmak mümkündür: "Türk kamuoyunun anlayamadığı iki veya üç konu daha vardır. Türkiye'nin Müttefikler ile işbirliğini en kuvvetli şekilde destekleyen Yalçın şunları sormaktadır: (1) İngiltere neden hala Romanya petrol alanlarını bombalamadı; (2) Brest'e yapılan 11 bombalama taarruzundan sonra Gneisenau ve Scharnhorst savaş gemileri neden hala batmadı veya kullanılamaz duruma gelmedi; (3) İngiliz Deniz ve Hava Kuvvetleri nasıl olurda Almanların tank ve araçlar içeren kocaman bir orduyu Kuzey Afrika'ya indirmesine engel olamadı. Bu sorular İngiltere'ye karşı düşmanca bir tavır içerisinde değil, Müttefik bir ülkenin insanlarının kafalarını karıştıran noktalar hakkında bilgi isteyen bir ruh hali ile sorulmaktadır."

\subsection{Irak ve Suriye Gelişmeleri}

Irak'ta 3 Nisan 1941 tarihinde gerçekleşen hükümet darbesi sonucu Nazi yanlısı Raşit Ali'nin iktidara gelmesi, Almanya'nın bu olay ile hemen hemen eş zamanlı olarak gerçekleşen Balkan seferinin yarattığı kaygıyı daha da artırmıştır. İngiltere ise Irak’taki bu gelişme sonrasında hemen harekete geçmiş ve yeniden kontrolü sağlamak üzere Irak'taki askeri mevcudiyetini artırmıştır. Almanya'nın Fransa'yı işgali sonrasında kurulan Vichy Hükümeti'nin aynı dönemde Suriye'de kontrolü elinde tutması ise, Türkiye'nin hissettiği kuşatılmış duygusunu daha da derinleştirmiş̧tir.

6 Mayıs 1941 tarihinde "New Anxiety for Turkey (Türkiye için Yeni Bir Kayg1)" başlığı ile The Times gazetesinde yer alan haberde Türkiye'nin kendisini kuşatan Mihver çemberi karşısında duyduğu tedirginlik açıkça görülmektedir: "Türkiye, İngiltere ve Irak arasındaki çatışmayı kaygı ile izlemektedir. Bu çatışma, bir süreliğine de olsa, Basra'ya giden demiryolunun kaybedilmesi tehdidini yaratmaktadır ki, bu demiryolu savaşın Akdeniz'e sıçramasından bu yana Türkiye'nin hem Batı'ya hem de Doğu'ya yaptı̆̆ ticaret için en önemli güzergah olmuştur. Ayrıca, çatışmanın uzaması halinde Almanya'nın, Türkiye'nin bir başka sınırına daha ulaşabilmek için yeni yollar ve araçlar bulabileceği yönünde daha da derin bir kayg1 bulunmaktadır. Burada, Irak’taki krizin Almanya kaynaklı olduğu genel olarak kabul görmektedir. Alman ajanlarının Irak'taki faaliyetleri Ankara'da yaygın olarak konuşulmaktadır." Haberin son bölümünde ise Suriye'deki gelişmelere yer verilmektedir: “...Ankara'ya ulaşan raporlar, Suriye'deki Fransız denetiminin, savaştaki değişime göre bir gün İngiliz yanlısı, bir başka gün Alman yanlısı olan Suriyelilerin eline geçtiğini belirtmektedir. Türk görüşüne göre, Suriye ortalığı karıştırmak isteyenler için firsatlar sunmaktadır. Bazı çevrelerde tehlikenin, Almanların turist ve işadamı kılığında sızdığı yönünde raporların geldiği İran'dan gelmesi beklenmektedir. Bununla birlikte, Türk yetkililer İran'dan gelecek bir sorun beklememektedir. Şah'ın otoritesi sağlam ve İran'daki Alman yanlısı hava, Alman yanlısı bir politikanın belirtisi olmaktan çok, Sovyetler Birliği’nin uyguladığı baskıya karşı bir tepkidir." ${ }^{\prime 5}$

İngiltere'nin Irak'ta Nazi yanlısı Raşit Ali yönetimini askeri yöntemle devirmesinin Türkiye'deki etkileri ve artık Suriye'deki gelişmelere yönelen dikkati ise 6 Haziran 1941 tarihli The Times'da yer alan "Turkish Anxiety over Syria (Türkiye'nin Suriye Kaygıs1)" başlıklı

44 "Explanations in Turkey", The Times, 01 Mayıs 1941, s. 3.

45 "New Anxiety for Turkey", The Times, 06 May1s 1941, s. 4. 
haberde görülmektedir: “Türkler, İngiltere'nin Irak'ta elde ettiği ve bir dereceye kadar Girit'in kaybını telafi eden başarısından son derece memnuniyet duymaktadır...Tüm gözler artık Suriye'ye çevrilmiş durumda. Türk görüşüne göre, tek soru, Almanların mı yoksa İngilizlerin mi oraya ilk ulaşacağıdır. Özgür Fransa'nın generalleri olan de Gaulle ve Catroux'un General Maitland Wilson ile görüşmelerde bulunmak üzere Filistin'e ulaştığı ve Suriye'ye sürekli Alman sızmasının söz konusu olmasına rağmen, bir İngiliz harekatının yakın olduğu yönünde raporlar var. Suriye ile ilgili Alman niyeti, sınırında Orta Doğu'yu ilgilendiren çatışmaların olması durumunda Türkiye'den tarafsızlık teminatı almaya yönelik ilgilerinde görülmektedir. Olaylara karışmak istemeyen Türkiye için zor bir durum ancak Suriye'nin kaderi ile de yakından ilgili. Eğer İngiltere Almanya'yı alt ederse, Türkiye'nin sorunu çözülecektir."46

\subsection{Türk-Alman Saldırmazlık Antlaşması}

Hitler, Sovyetler Birliği'ne karşı harekete geçme tarihini 15 Mayıs 1941 olarak saptamıştı. Hitler, Sovyetler Birliği'ne karşı harekete geçmeden önce İnönü'ye 4 Mayıs'ta yazdığı bir mektupla iki ülke arasında bir saldırmazlık paktı akdini önerdi. Bu düşünce ile yapılan görüşmeler sonucunda Dışişleri Bakanı Şükrü Saraçoğlu ile Almanya'nın Ankara Büyükelçisi von Papen arasında 18 Haziran 1941'te bir Dostluk ve Saldırmazlık Paktı imzalandı. Böylece, Hitler Sovyet Rusya ile savaşırken sağ kanadını güvence altına almak istemişti. Türkiye bu paktı imzalarken İngiltere ile ittifakının kendisine yüklediği yükümlülüklerine bağlı kalacağını ifade etti. ${ }^{47}$

Volume 12

Issue 5

October

2020

Türk-Alman Saldırmazlık Antlaşması'nın imzalanması, 19 Haziran 1941 tarihli "Turkish Treaty with Berlin (Türkiye'nin Berlin ile Antlaşması)" başlıklı haber ile İngiliz kamuoyuna duyurulmaktadır: "Alman haber ajansı dün gece Türkiye'nin Berlin ile "her iki ülkenin mevcut taahhütleri çerçevesinde" bir "Dostluk Antlaşması" imzaladığını duyurdu. Yakın Doğu'daki zaferlerin, batı sınırlarına Mihver Güçleri'nden oluşan bir yarım ay getirmesinden bu yana Türkiye üzerinde bu yönde büyük bir baskı uygulanmıştır. Alman askerleri Trakya ve Ege Adaları'nda bulunmaktadır ve Dobruca ve Rodos üzerinden İtalyanlar ile bağlanmaktadır. Türkler görüşmeler sırasında İngiliz Hükümeti'ni gelişmelerden haberdar etti. Kayda değer bir direnç gösterdiler ve Almanya'nın istediklerinin hepsinin karşılanmadığı açıktır. Bununla birlikte, Antlaşma her iki tarafa da karşılıklı olarak toprak bütünlüğü ve saldırmazlığı ve, ortak konularla ilgili tüm sorunlarda konsültasyonu garanti etmektedir. Bu durum, Almanya'nın daha fazla imtiyaz için bastıracağı anlamına gelmektedir. Antlaşmanın imzasının Londra'da memnuniyetle karşılandığ 1 ise söylenemez ancak Türkiye'nin içinde bulunduğu zor durum tam olarak anlaşılmaktadır..."48

Türk-Alman Saldırmazlık Antlaşması'nın İngiltere'de uyandırdığı tepkileri anlamak için 21 Haziran 1941 tarihinde The Times gazetesinde "Turkish Pact with Berlin (Türkiye'nin Berlin ile Paktı)" başlığı ile yayınlanan habere bakmak yeterli olacaktır: "Hiç şüphesiz, İngiltere'deki birçok kişi (ve Türkiye'de hatırı sayılır sayıda kişi) Türk tavrını kafa karıştırıcı bulacaktır ve Türkiye'nin İngiltere ile olan ittifakının artık ne kadar değerli olduğunu sorgulayabilir. Cevap

46 "Turkish Anxiety over Syria", The Times, 06 Haziran 1941, s. 4.

${ }^{47}$ Tuncer, age, s. 97.

48 “Turkish Treaty with Berlin", The Times, 19 Haziran 1941, s. 4. 
İkinci Dünya Savaşındaki Mihver İlerleyişinin Türk Dış Politikasına Etkilerinin...

bugün sıkça duyulan şu soruda gizlidir: “Irak ve Suriye'deki olaylar 1şığında ve tamamen İngiliz bakış açısı ile, Türkiye, Yugoslavya ve Yunanistan ile birlikte savaşsaydı ve Almanya'nın saldırısına uğrasaydı ve muhtemelen de yenilseydi daha $m ı$ iyi olurdu? Ya da, şu anki sağlam yapısı ile Almanya'nın Orta Doğu'ya doğru hareketinde bir engel mi teşkil etmesi tercih edilir? Ayrıca, Türkiye tarafından İngiltere’ye, Türk-İngiliz ittifakı gereğince Alman askerlerinin ve savaş materyalinin topraklarından geçişinin reddedildiği teminatının verildiği anlaşılmaktadır. Paktın sonucu muhtemelen, Türkiye ve Almanya arasında ticaretin (Almanya özellikle Türk kromu ile ilgilenmektedir ve bu da Türkiye'nin İngiltere'ye olan borçlarının karşılığıdır) artması olacaktır. Papen, Türkiye'yi "yeni düzenin” savunucuları ile bir şekilde işbirliğine girmeye iknaya çalsşabilir...Bu fanatik düşüncelerdeki gerçek ne olursa olsun, bu yeni paktın imzalanması bir şekilde Almanya'nın Rusya ile ilgili planlarına bağlanılabilir. Muhabiriniz, Sovyetler Birliği’nin Türkiye tarafından, İngiltere'ye yapıldığı gibi, pakt ile ilgili görüşmelerden haberdar edilip edilmediğini ve geçen hafta Ankara'daki Sovyet Büyükelçisi'nin Moskova'ya gitmesinin bununla ilgili olup olmadığını teyit etmeye çalıştı. Ancak kesin bir yanıt alamadı ama yorumlar oldukça olumsuz. Almanya'nın Rusya ile ne yapacağı hala bir spekülasyon konusu ve buraya gelen raporlar oldukça çelişkili. Romanya'dan gelen haberler çok endişe verici. Köstence halkı tahliye edildi ve İstanbul limanındaki Romanya gemilerinin Karadeniz'e açılma planlarının iptal edilmesi talimatı verildi. Alman planları ne olursa olsun, Türkiye bu planlar içerisinde yer almaktadır ve muhtemelen bu rol, Rusya'ya karşı bir saldırı durumunda Alman kanadına tampon işlevi görmek olacaktır." 49

\subsection{Almanya'nın Sovyetler Birliği'ne Saldırısı}

Alman Ordularının 22 Haziran 1941 sabahı Polonya toprakları üzerinde Alman-Sovyet ortak sınırını geçerek genel bir saldırı başlattıkları ve Almanya ile Sovyetler Birliği arasında savaşın başladığı haberi Türkiye'nin üzerinden büyük bir yükü kaldıracaktır. Türk Hükümeti o zamana dek, kendi üzerinde yapılmış bir pazarlık sonucunda oluşmuş olası bir Alman-Sovyet işbirliği ve antlaşmasından her zaman kuşku duymuştu. Savaş, bu kuşku ve endişeleri kendiliğinden dağıttı. Ancak, Almanya ile Sovyetler Birliği arasındaki savaş Türkiye'nin savaşın başından beri savaşa katılmamak için müttefiklere karşı kullandığı iki numaralı protokolü "Sovyet Çekincesi" gerekçesini de artık kullanılmaz hale getiriyordu. ${ }^{50}$

Almanya'nın Türkiye ile imzaladığı Saldırmazlık ve Dostluk Antlaşması'nın yankıları henüz devam ederken, bu Antlaşma'nın esas nedeni 22 Haziran'da anlaşılmıştı. 24 Haziran tarihli The Times'da "Turkey to Stay Neutral (Türkiye Tarafsız Kalacak)" başlığı ile yayınlanan haberde Türkiye'nin Alman-Rus çatışmasındaki resmi pozisyonu bildirilmektedir: "Ankara'dan yapılan resmi açıklamada, Türk Hükümeti'nin Almanya ve Rusya arasındaki çatışmada kesinlikle tarafsız kalmaya karar verdiği belirtildi. Dışişleri Bakanı Saraçoğlu dün Papen'i ve Sovyetler Birliği maslahatgüzarını kabul etti. Bu sabah da, hafta sonunu geçirdiği İstanbul'dan acele bir şekilde Ankara'ya dönen İngiliz Büyükelçisi Hughe Knatchbull-Hugessen'i kabul etti. Saraçoğlu'nun tüm taraflara Türkiye'nin tarafsızlığına saygı duyacaklarına olan inancını belirttiği ve savaşan ülkelerin temsilcilerine, Türkiye'nin Montreux Konvansiyonu çerçevesinde

49 “Turkish Pact with Berlin”, The Times, 21 Haziran 1941, s. 3.

${ }^{50}$ Koçak, age, s. 599. 
Boğazların bekçisi olarak görevlerini yerine getirmeye devam edeceği yönünde teminat verdiği düşünülmektedir...Geçtiğimiz kış ve ilkbaharda sıkça dillendirilen bir teoriye göre, Balkanlardaki Alman harekatları kendi içinde bir amaç değildi, daha ziyade Rusya'ya karşı yapılacak bir saldırıda Alman kanadını kapatmak için bir araçtı. Bu teori şu anda tam anlamıyla teyit edilmiştir. Almanlar, Karadeniz'de Köstence, Varna, ve Burgaz'da sağlam üslere sahipler ve Ege adalarını işgal ederek de Çanakkale Boğazı ve İstanbul Boğazı'nı kontrol edebilecekleri mükemmel bir pozisyona geldiler. Son olarak, birkaç gün önce Türkiye ile imzalanan pakt da açık olan tek boşluğu doldurdu ve Almanya'yı, Rusya ile olan hesabını görürken tam anlamıyla güvenlik çemberine ald.." 51

Savaşan tarafların Türkiye'yi yanlarına çekmek üzere yaptıkları propaganda faaliyetleri kapsamında Türkiye hakkında çıkarılan bazı yalan haberler, 1 Temmuz 1941'de The Times'da "Turkish Attitude to Russia (Türkiye'nin Rusya Tavrı)" başlıklı haberde yer almaktadır: "Anadolu Ajansı bu günlerde, Türkiye'nin politikası hakkında yurt dışında yayınlanan raporlar hakkında yorum yapmakla veya onları düzeltmekle oldukça meşgul. Bu bağlamda, Anadolu Ajansı, Papen'in Dışişleri Bakanı Saraçoğlu vasıtasıyla İngiliz Büyükelçisi Hughe KnatchbullHugessen'e barış teklifi yaptığı haberini yalanladı. Ayrıca, Türkiye'ye Almanya tarafından Kafkasların bir kısmının teklif edildiği ve Eden'in Türkiye'nin Londra' daki büyükelçisi Dr. Aras ile yaptığı görüşmede Türkiye'nin Rusya'ya karşı dostane olmayan tavrının ele alındığ şeklindeki raporu da yalanladı ve fantastik olarak değerlendirdi. Son olarak, Moskova'dan, Hitler'in Rusya'nın Boğazlarda üs istediği şeklindeki iddialarını yalanlayan bir açıklama ile birlikte Molotoff'un 22 Haziran'da yaptığı bir yalanlama konuşması Anadolu Ajansı'nın servis ettiği şekliyle Türk basınında yer aldı..."52

Mayıs ve Haziran 1941 tarihlerine kadar, Sir Alexander Cadogan ve Sir Orme Sargent gibi Foreign Office (İngiliz Dışişleri Bakanlığı) yetkilileri Sovyetler Birliği’ne karşı derin bir şüphe duyuyorlardı ve Stalin'in Hitler'i savaştan kaçınmak için yatıştıracağını bekliyorlardı. Bu şüphe, Ankara ile olan görüşmeleri Whitehall'da ifade edilenleri yansıtan Türk diplomatlar tarafindan da paylaşılıyordu. Ağustos ayına gelindiğinde, İngilizlerin görüşü çok farklıydı. "Rus fobisi" bir “Türk hastalığı” idi ve Türk'ün Rusya'ya bakışı, İrlandalının İngiltere'ye bakışına oldukça benziyordu. Asla unutmaz ve bastırılmış garezi, üzüntüsü dışında her şeye karşı onu kör eder. ${ }^{53}$

9 Temmuz 1941 tarihli The Times'da Türkiye'nin Alman-Rus savaşında arzu ettiği sonuç İngiliz muhabir tarafından açıklanmaktadır. "Divided Hopes in Turkey (Türkiye'nin Bölünen Ümitleri)" başlıklı haberde şunlara yer verilmektedir: “...Türk halkı arasında "İngiliz zaferi mi yoksa Alman zaferi mi istersiniz?” şeklinde bir araştırma yapılsa, dörtte üçü İngiltere cevabı verirdi. Aynı soru Almanya ve Rusya için sorulsa, sonuç oybirliği ile Almanya lehine olurdu. Kamuoyunun yaşadığı bu kafa karışıklığı, gelecekten beklentiler hakkında bir tür çekince yaratmaktadır. Türk halkının gerçek isteği, bugünlerde duyulan şu cümlede yatmaktadır: Keşke Hitler ve Stalin birbirini yere serse.” Haberin devamında ise, Türkiye'nin neden Sovyetler Birliği

51 "Turkey to Stay Neutral", The Times, 24 Haziran 1941, s. 4.

52 "Turkish Attitude to Russia", The Times, 01 Temmuz 1941, s. 3.

${ }^{53}$ Nicholas Tamkin, "Diplomatic Sigint and the British Official Mind during the Second World War: Soviet Claims on Turkey, 1940-1945", Intelligence and National Security, Vol. 23:6, 2009, s. 749-766. 
İkinci Dünya Savaşındaki Mihver İlerleyişinin Türk Dış Politikasına Etkilerinin...

hakkında şüpheci olduğu açıklanmaktadır: “...Rus şüphesi ve korkusu, atalarının Ruslar ile iki yüzyıldan fazla savaştı̆̆ını hatırlayan her Türk’te geçmişten bu yana bulunur. Rusya'da komünizmin, Türkiye'de de Kemalizm' in tesisinden itibaren 15 y1l boyunca bu uzun soluklu çatışmaya ara verildi. Ancak barış bozuldu ve Türkler, hiç de haksız olmayarak, bunun kendi suçları olmadığını düşünmektedir. Ağustos 1939 tarihli Alman-Rus Antlaşması, Saraçoğlu'nun sonuçsuz Moskova ziyareti ve Sovyetler Birliği’nin son iki yıldaki gizemli tavırları Türkiye'de Rus planları ve niyetleri hakkında gerginliğe ve huzursuzluğa yol açmaktadır ve bu hava bu yıl 24 Mart'ta imzalanan Tarafsızlık Deklarasyonu ile zar zor dağılmıştır. Tam da bu anda, Rusya'nın sözde Türkiye tasarıları ile ilgili Alman açıklamaları geldi. Hitler'in, Molotoff'un Boğazlar'da üs istediği şeklindeki açıklaması Papen'in uzun bir süredir Ankara'da fisıldadıklarını teyit etti. Ayrıca, Sofya'dan Ankara'ya, Rusya'nın Bulgaristan'a Enes-Köstence hattını, Rus-Bulgar işbirliğinin bir ödülü olarak teklif ettiği yönünde raporlar ulaştı." ${ }^{4}$

16 Temmuz 1941 tarihinde The Times'da "Turkish Fears of Russia (Türklerin Rus Korkusu)" başlıklı haberde açıklanan İngiliz-Rus Antlaşması, Türkiye'nin Müttefikler ve Mihver ile olan ilişkilerini gölgeleyecek bir kara bulut olacaktır: "İngiliz-Rus antlaşmasının imzalanması Türkiye'de oldukça soğuk karşılandı. Churchill 22 Haziran'da yaptı̆̆ı konuşmasında, İngiltere'nin Rusya ile işbirliği yapmak istediğini açıklamıştı ancak Türkler, İngiliz desteğinin niteliksiz ve gönülden olup olmayacağı konusunda hala şüpheliler. Bu yeni antlaşma bu şüpheleri ortadan kaldırıyor ve Türkler şimdi de İngilizler ile olan ittifakları ile Litvinov'un en son konuşmasındaki Türkiye referanslarından bu yana her geçen gün daha da belirgin hale gelen Rus korkularını uzlaştırma sorunu ile karşı karşıyalar. Türk-Alman paktı imzalandığında, Türklerin sloganı "İngilizler ile İttifak, Almanlar ile Dostluk" idi. Durumun nazik olmasına rağmen, Türkiye'nin tedbirli ve dikkatli bir şekilde idare edebileceği umuluyordu. Buna karşın, şimdi de, Türklerin Moskova Emperyalizmine karşı duyduğu eski ön yargıları canlandıran Alman-Rus savaşının getirdiği karmaşıklık söz konusu..."55

Rusya'nın savaşa dahil olması üzerine, İngiltere ve Rusya ilk olarak 12 Temmuz 1941 günü İngiliz Sefiri ile Stalin'in imzaladıkları siyasi nitelikte bir anlaşma yaptılar. Anlaşma, kalite ve miktar belirtmeden tarafların birbirlerine yardım edeceklerini ve ayrı barış yapmayacaklarını ön görüyordu. Bu anlaşma da Türkiye'de bir endişe uyandırdı. İngiltere anlaşmayı imzalarken, RusAlman savaşına seyirci kalıp, hatta Almanya ile anlaşıp, Rusya'nın ezilmesine zemin hazırlayacağı yolundaki Rus endişelerini bertaraf etmek istemişti. Türkiye hem bu niyeti, hem de anlaşmanın gizli hükümleri olup, olmadığını bilmiyordu. ${ }^{56}$

13 Ağustos 1941'de "Guarentee to Turkey (Türkiye'ye Garanti)" başlı̆̆ yayınlanan haber, Türkiye'nin İngiliz-Rus Antlaşması'ndan duyduğu rahatsızlı̆̆ı ortadan kaldırmaya yönelik çabaları anlatmaktadır: "İngiliz ve Rus Hükümetleri, Ankara'daki büyükelçileri vasıtasıyla, Türkiye'ye saldırıya uğraması durumunda her türlü yardımı yapmaya hazır olduklarını açıkladılar. Aynı zamanda, Türkiye'nin toprak bütünlüğüne ve Boğazlar ile ilgili konvansiyonlara olan saygılarını da bir kez daha yenilediler. Sözlü açıklamasında Rus

54 "Divided Hopes in Turkey", The Times, 09 Temmuz 1941, s. 3.

55 "Turkish Fears of Russia", The Times, 16 Temmuz 1941, s. 4.

56 Kamuran Gürün, Savaşan Dünya ve Türkiye, Tekin Yayınevi, İstanbul 2000, s. 242. 
Büyükelçisi, Türkiye ile Sovyetler Birliği arasında çatışma tohumları ekmeyi amaçlayan Alman çabalarını kınadı. Deklarasyonlar memnuniyetle karşılandı..." ${ }^{57}$

\subsection{Türk-Alman Ticaret Antlaşması}

Almanya'nın Balkanlarda 1941 ilkbaharından itibaren etkisini artırmaya başlaması, Türk Hükümeti'ni Almanya ile bir saldırmazlık antlaşması imzalamaya sevk etti. İngiltere'nin bir müttefikinin Almanya ile de bir saldırmazlık antlaşması imzalamasının oldukça paradoksal görünmesine rağmen, Türkiye hem siyasi hem de ekonomik olarak ayakta kalmanın yollarını bulmak zorundaydı. 1930'lardaki ile karşılaştırıldığında, 1940 yılında Türk-Alman ticareti düşük bir seviyedeydi ancak Eylül 1941'de ticaret antlaşması görüşmeleri başladı. Dışişleri Genel Sekreteri Numan Menemencioğlu'nun hem Amerikalılara hem de İngilizlere, hükümetinin Almanlara gelecekte krom satmayı reddedeceğinin teminatını vermesine rağmen, geçmişte olduğu gibi, bu görüşmelerde de "Türkiye'den Almanya'ya krom ihracatı" en önemli konu olmuştur. Türk tarafı Almanlara, kromun sadece savaş malzemesi karşıllğında ihraç edileceğini ve İngiltere ile imzalanmış olan "Krom Antlaşması" nedeniyle 1943 yılına kadar hiçbir teslimatın yapılamayacağını belirtti. Alman Delegasyonu'nun başında bulunan Dr. Clodius, Menemencioğlu'na Almanya'nın, Türkiye'nin 1943 Ocak ayına kadar tüm krom üretimini İngiltere'ye satmayı taahhüt etmiş olmasına saygı duymasına rağmen, Almanya'nın Türkiye'nin 1943 ve 1944 yıllarındaki üretiminin yarısını talep ettiğini gizli mektup alışverişi ile Menemencioğlu'na iletti. ${ }^{58}$

Türk-Alman Ticaret Antlaşması, hiç şüphesiz İngiltere'yi çok yakından ilgilendiriyordu. Gelişmeleri dikkatle takip eden İngiliz basınında ilk haberler Ağustos ayından itibaren çıkmaya başladı. 21 Ağustos 1941 tarihli The Times, "Turkey No Vassal to Axis (Türkiye Mihver'e Bağımlı Değil)" başlığı ile şu haberleri vermektedir: Türk halkı, yeni bir ticaret antlaşmasının imzası için yakında gerçekleştirilecek Türk-Alman görüşmelerinin "yeni düzenin çerçevesi içerisinde" olacağını ve İngiltere ile olan ticaretinin tamamen kesilmesi karşısında Türkiye'nin Almanya ile ticari ilişkilerini geliştirmekten memnuniyet duyacağını anlatan Alman propaganda yayınları karşısında şok oldu..." Haberin devamında Türk Dışişleri Genel Sekreteri Numan Menemencioğlu ile ilgili olarak sarf edilen övgü dolu sözler, Menemencioğlu'nun yakın gelecekte İngilizlerin boy hedefi haline geldiği düşünüldügünde, sadece ironik olarak değerlendirilebilir: "'Yeni düzenin' ekonomi alanındaki ünlü uzmanı olan Clodius, Türkiye ile gerçekleştirilecek görüşmelerde delegasyon başkanlığı yapacak. Eğer bu doğruysa, Clodius gibi birisinin Türkiye'ye 25 milyon sterlinlik orta büyüklükteki bir antlaşma için gelmesi ihtimal dışıdır. Daha büyük amaçlarının olduğu kesindir. Ancak, karşısında, Türk Delegasyonuna başkanlık yapacak ve Türk diplomatları arasında en yeteneklilerden ve zekilerden birisi olmanın yanı sıra, benzer antlaşmaların görüşmelerinde oldukça tecrübe kazanmış olan Türk Dışişleri Genel Sekreteri Numan Menemencioğlu'nu bulacak. Almanlar Türkiye’yi Romanya, Macaristan

\footnotetext{
57 "Guarentee to Turkey", The Times, 13 Ağustos 1941, s. 4.

${ }^{58}$ Gül İnanç, "The Politics of Active Neutrality on the Eve of a New World Order: The Case of Turkish Chrome Sales During the Second World War", Middle Eastern Studies, Vol. 42:6, 2007, s. 907-915.
} 
İkinci Dünya Savaşındaki Mihver İlerleyişinin Türk Dış Politikasına Etkilerinin...

ve "yeni düzenin" diğer talihsiz kurbanları gibi bir ekonomik bağımlı haline getirme ümidine sahiplerse, kesinlikle hayal kırıklığına uğrayacaklardır." 59

Yukarıda aktarılan haber ile aynı gün The Times'da yayınlanan başyazıda benzer görüşler ile birlikte ilginç bir tarihi referansa yer verilmektedir: "Türkler "yeni ekonomik düzenden" etkilenmemiştir. Onlara göre, bu düzenin çerçevesi bir kafesin tellerine benzemektedir ve yeni bir Timur'un kontrolünde olacak bir Beyazıt istememektedirler...Görüşmelerde Türkiye'yi temsil edecek olan Numan Menemencioğlu'nun kişiliğinde, Türkiye, beş yıl önce Dr. Schacht'ın ekonomik ağından kaçarken kendi rolünü oynayan ve ticari antlaşmalarda geniş bir tecrübeye sahip olan yetenekli bir diplomata sahip olacaktır."60

Türk-Alman Ticaret Antlaşması'nın görüşmeleri 8 Eylül 1941 tarihinde Ankara'da başladı ve bunun haberi 9 Eylül tarihli The Times'da "German Bait for the Turks (Türklere Alman Yemi)" başlığı ile yayınlandı: “ Türkiye ile Almanya arasındaki ticari görüşmeler, Clodius'un ve Alman delegasyonunun geri kalanının gelişinden hemen sonra burada resmen başladı. Alman çevrelerinden gelen raporlara göre, Clodius'un getirdiği öneriler ezici yapıda ve Türkiye'deki tüm ürünleri Almanya'ya yönlendirmeyi amaçlıyor. Bu amacı gerçekleştirmek için Clodius'un, madencilik ve yağ tohumu üretiminin bir kısmı için Reichmark olarak kredi, tüm alımların ücretinin yüzde 30'unun nakdi olarak önceden, geri kalanının ise takas olarak ödenmesi ve Türkiye'nin arzu ettiği miktarda uzun vadeli borçlanması gibi özel finansal kolaylıklar sunmaya hazırlandığ 1 söylenmektedir. Bu teklifler oldukça belirsizdir ve ticari takas için bir temel oluşturmamaktadır. Almanlar Türkiye'den tahıl, kuru meyve, yağ tohumu, tiftik, manganez ve krom almak ve karşıllğında makine ve yedek parça, elektrikli aletler, silah ve cephane, demiryolu ekipmanı ve kimyasal maddeler vermek için istekli görünüyorlar...Ticari açıdan bakıldığında, Clodius'un önerileri uygulama bakımından büyük firsatlar sunmuyor. Esas amaçlarının, saf iş anlaşması olmaktan ziyade siyasi propaganda olduğu izlenimini vermektedirler."61

23 Eylül 1941 tarihinde The Times'da "Turkish Suspicious of Germany (Türkler Almanya'dan Şüphe Duyuyor)" başlıklı haberde Türk tarafının Türk-Alman görüşmeleri sırasında duyduğu kaygıları ve bunları gidermek üzere attığı adımları anlatmaktadır: “...geçmiş tecrübeler ile daha da uyanık hale gelen Türk görüşmeciler, takasların mümkün olduğunca eş zamanlı olarak gerçekleşmesi konusunda özel dikkat gösteriyorlar. Bu, yeterli teslimat olmadan büyük miktarlarda Alman alımı ihtimalini devre dışı bırakmayı amaçlamaktadır ki, böyle bir durum Türkiye'yi, daha önce olduğu gibi, istekleri karşılanmamış bir alacaklı durumuna getirir. Bu sefer, takaslar İstanbul'da gerçekleşecek ve Türk malları Alman karşılıkları gelmeden sevk edilmeyecek. Almanların, kendileri için oldukça yararlı olan yerel ürünler karşılığında diğer ülkeleri çocuk oyuncaklarına, fotoğraf makinelerine ve diğer istenmeyen kalemlere boğmaları şeklindeki alışılageldik hilelerini oynamamaları için adımlar atılacaktır. Türkler, takas edilen malların her iki taraf için de eşit derecede yararlı olmasını gözetecektir." ${ }^{\circ 2}$

59 “Turkey No Vassal to Axis", The Times, 21 Ağustos 1941, s. 4.

60 "The Turks and the New Order", The Times, 21 Ağustos 1941, s. 5.

61 "German Bait for the Turks", The Times, 09 Eylül 1941, s. 4.

62 "Turkish Suspicious of Germany”, The Times, 23 Eylül 1941, s. 4. 


\begin{abstract}
Almanya, dünyada en çok Türkiye'nin sahip olduğu krom meselesinde istediği başarıyı elde edemedi. Krom ticareti, ekonomik olduğu kadar siyasi bir sorundu. Antlaşmayla Almanya'ya herhangi bir taviz verilmedi. Krom 1941 ve 1942 yılları için İngiltere'ye ve Fransa'ya ayrıldığından Almanya'ya satışı mümkün değildi. 1943 Ocak ayı için ise, Almanlar 150 bin ton istemişti ancak Türkiye Almanya'nın 1942 sonuna kadar 18 milyon sterlin değerinde savaş malzemesini Türkiye'ye getirmesi karşılı̆̆ında 1943-44 yılları için yıllık 90 bin ton krom satmayı kabul etti. ${ }^{63}$

İngiltere'nin, Türk-Alman Ticaret Antlaşması'nın özellikle krom satışını içermemesi yönündeki tüm çabalara karşın, Antlaşmanın geleceğe yönelik krom satışını içermesi İngiltere'de hayal kırıklığına yol açmıştır. Ancak, Türkiye'nin içinde bulunduğu durum anlayışla karşılanmıştır. Bu görüş, 10 Ekim 1941'de "Turkish-German Pact Signed (Türk-Alman Paktı İmzalandı)” başlığı ile Türk-Alman Ticaret Antlaşması'nın imzalandığını duyuran The Times haberinde de açıkça görülmektedir: "Türkiye ile Almanya arasındaki yeni ticaret antlaşması bugün öğleyin imzalandı. İmza sırasında Papen de hazır bulundu. Clodius ve beraberindekiler yarın Türkiye'den ayrılıyorlar. Görüşmeler aslında, Alman delegasyonunun Türkiye'nin krom ile ilgili karşı teklifini kabul ettiği dün sona erdi. Türkiye Almanya'ya, Türk-İngiliz Antlaşması sona erdikten sonra, 1943 yılında 90 bin ton, 1944 yılında da aynı miktarda krom sağlamayı, 1942 yılının sonuna kadar Almanya'nın 18 milyon sterlin değerinde savaş materyalini Türkiye'ye teslim etmesi ve ayrıca söz konusu iki yıl boyunca Türk kromuna karşılık olarak Almanya'nın eşit miktarda savaş materyali teslim etmesi şartıyla kabul etti. Giderek uzayan ve zorlu görüşmeler sırasında Türk Hükümeti, İngiliz ve Alman ihtiyaçları ile ilgili taahhütler arasında oldukça nazik bir pozisyonda idi. Oldukça sadık davrandılar ve İngiliz Hükümeti'ni görüşmeler ve durumun zorluğu hakkında sürekli haberdar ettiler. İngiliz bakış açısından, Türkiye'nin kendisini gelecekte Almanya'ya krom sağlamak üzere taahhüt altına alması tercih edilmezdi. Bununla birlikte, Türk Hükümeti bu şartlar altında elinden gelenin en iyisini yaptı ve Almanya'nın güçlü muhalefetine rağmen 8 Ocak 1942 tarihinden sonra İngiltere ile olan krom antlaşmasını bir yıl daha uzatmayı kabul etmesi iyi niyetlerinin ve sadakatlerinin bir kanitıdır..." 64
\end{abstract}

\title{
Sonuç
}

Almanya öncülüğündeki Mihver Devletlerinin İkinci Dünya Savaşı'nın ilk yıllarında Avrupa'da elde ettiği askeri üstünlük, bu dönemde Türkiye'nin izlediği dış politikayı şekillendiren temel unsur olmuştur. Türk dış politikasındaki bu Mihver etkisi, Türkiye ile savaşın hemen başında ittifak antlaşması imzalayan İngiltere'de 18. yüzyıldan bu yana yayınlanmakta olan The Times gazetesinin Türkiye ile ilgili olarak bu dönemde yayınladığı haberlerde açıkça görülmektedir. İngiliz hükümetinin savaş boyunca adeta sesi olan ve hükümetin sesini hem içeride hem de dışarıda duyuran The Times gazetesinin İkinci Dünya Savaşındaki Mihver üstünlüğü sırasında Türkiye ile ilgili olarak yaptığı haberler incelendiğinde, bunların İngiliz dış

\footnotetext{
${ }^{63}$ Süleyman Seydi, Zor Yıllar 2. Dünya Savaşı 'nda Türkiye'de Ingiliz-Alman Propaganda ve İstihbarat Savaşı, Asil Yayın Dağıtım, Ankara 2006, s. 15.

64 “Turkish-German Pact Signed", The Times, 10 Ekim 1941, s. 3.
} 
İkinci Dünya Savaşındaki Mihver İlerleyişinin Türk Dış Politikasına Etkilerinin...

politikası ile birebir uyuştuğu görülmektedir. Bu inceleme sonucunda, bir zincirleme reaksiyon ortaya çıkmaktadır: Mihver ve Müttefik baskıları Türk dış politikasını etkiliyor, Türk dış politikasındaki değişiklikler ise The Times'da çıkan haberleri belirliyordu. Sonunda, Türk kamuoyu da İngiliz basınını takip ederek, bu karanlık dönemde kendi yolunu belirlemeye çalışıyordu.

Sonuç olarak, The Times gazetesi yayınladığı haberler ve yorumlar ile İngiliz kamuoyunun ve hükümetinin Türkiye ile ilgili düşüncelerini duyurmuş ve Türkiye'den gelen yanıtları da ülkesine haber vermiştir. Bu bakımdan, İkinci Dünya Savaşının ilk yıllarında Avrupa'da yaşanan Mihver üstünlügünün Türk dış politikasına olan etkilerinin anlaşılmasında, The Times gazetesinde çıkan haberlerin bilinmesi ve değerlendirilmesi, söz konusu dönemi ele alan çalışmaların eksiksiz olması açısından değerlidir.

\section{Kaynakça}

\section{Gazeteler}

The Times

“Turkey Loyal to Peace Front”, The Times, 3 Eylül 1939.

"Watchfulness in Turkey / All Eyes Turned on Italy", The Times, 6 Eylül 1939.

“Turkish Sympathies with the Allies”, The Times, 8 Eylül 1939.

“Turkey’s Delicate Position”, The Times, 19 Eylül 1939.

“Turco-Bulgarian Relations”, The Times, 27 Ocak 1940.

"Self Help in the Balkans", The Times, 02 Şubat 1940.

"Italian Advice to Balkans", The Times, 02 Şubat 1940.

"German Eyes on Belgrade", The Times, 03 Şubat 1940.

"First Impressions in Turkey”, The Times, 06 Şubat 1940.

“Turkey Stands by Her Friends", The Times, 21 Mayıs 1940.

“Turkey Remains Calm”, The Times, 24 Mayıs 1940.

“Turkey Anxious but Calm”, The Times, 19 Haziran 1940.

"French Commander's Visit to Angora", The Times, 04 Haziran 1940.

“Turkey and Rome Assurances”, The Times, 05 Haziran 1940.

"Mussolini Enters the War", The Times, 11 Haziran 1940.

“Turkey's Watch on Events”, The Times, 17 Haziran 1940.

"When Turkey Will Move", The Times, 30 Ekim 1940.

“Turks on Greek Resistance", The Times, 08 Kasim 1940.

"If Bulgaria Attacks Greece", The Times, 21 Kasım 1940.

“Turkish Service to Greece”, The Times, 27 Kasim 1940. 
“Turkey on Guard”, The Times, 07 Nisan 1941.

"Precautions in İstanbul", The Times, 14 Nisan 1941.

"Nazi Designs on Turkey”, The Times, 19 Nisan 1941.

"Explanations in Turkey", The Times, 01 Mayis 1941.

"New Anxiety for Turkey", The Times, 06 Mayıs 1941.

“Turkish Anxiety over Syria”, The Times, 06 Haziran 1941.

“Turkish Treaty with Berlin”, The Times, 19 Haziran 1941.

“Turkish Pact with Berlin”, The Times, 21 Haziran 1941.

“Turkey to Stay Neutral”, The Times, 24 Haziran 1941.

"Turkish Attitude to Russia", The Times, 01 Temmuz 1941.

"Divided Hopes in Turkey", The Times, 09 Temmuz 1941.

"Turkish Fears of Russia", The Times, 16 Temmuz 1941.

"Guarentee to Turkey", The Times, 13 Ağustos 1941.

“Turkey No Vassal to Axis”, The Times, 21 Ağustos 1941.

"The Turks and the New Order", The Times, 21 Ağustos 1941.

"German Bait for the Turks", The Times, 09 Eylül 1941.

“Turkish Suspicious of Germany”, The Times, 23 Eylül 1941.

“Turkish-German Pact Signed”, The Times, 10 Ekim 1941.

\section{Tetkik Eserler}

ARMAOĞLU, Fahir, 20. Yüzyll Siyasi Tarihi, Alkım Yayınevi, İstanbul 2007.

AYDEMİR, Şevket Süreyya, İkinci Adam, Remzi Kitabevi, İstanbul 1985.

DERINGiL, Selim, Denge Oyunu İkinci Dünya Savaşı’nda Türkiye’nin Dış Politikası, Tarih Vakfi Yurt Yayınları, İstanbul 2009.

GÜRÜN, Kamuran , Türk-Sovyet Ilişskileri (1920-1953), Türk Tarih Kurumu Basımevi, Ankara 1991.

Savaşan Dünya ve Türkiye, Tekin Yayınevi, İstanbul 2000.

HART, Liddell, II. Dünya Savaşı Tarihi Cilt I, Çev: Kerim Bağnıçık, Yapı Kredi Yayınları, İstanbul 2000.

KOÇAK, Cemil, Türkiye'de Milli Şef Dönemi (1938-1945) Cilt 1, İletişim Yayınları, İstanbul 2003.

SANDER, Oral, Türkiye'nin Dış Politikası, İmge Kitabevi, Ankara 2000.

SEYDİ, Süleyman, Zor Yıllar 2. Dünya Savaşı'nda Türkiye'de İngiliz-Alman Propaganda ve İstihbarat Savaşı, Asil Yayın Dağıtım, Ankara 2006. 
İkinci Dünya Savaşındaki Mihver İlerleyişinin Türk Dış Politikasına Etkilerinin...

SHIRER, William L., Nazi İmparatorluğu Doğuşu, Yükselişi, Çöküşü, Çev: Rasih Güran, İnkılap Kitabevi, İstanbul 1992.

TUNCER, Hüner, İsmet İnönü 'nün Dış Politikası (1938-1950), Kaynak Yayınları, İstanbul 2012.

Türkçe Sözlük, Türk Dil Kurumu, Ankara 2011.

UZGEL, İlhan, "İtalya'yla İlişkiler”, Türk Dış Politikası, Ed. Baskın Oran, İletişim Yayınları, İstanbul 2003.

\section{Hatıratlar}

CHURCHILL, Winston, 2. Dünya Savaşı Hatıraları, Tek Başımıza Mücadele 1940, Çev: Mehmet Ali Yalkın, Örgün Yayınevi, İstanbul 2005.

\section{Makaleler}

DERINGIL, Selim, "The preservation of Turkey's neutrality during the Second World War: 1940”, Middle Eastern Studies, Vol.18, No.1, 1982, s. 30-52.

İNANÇ, Gül, "The Politics of Active Neutrality on the Eve of a New World Order: The Case of Turkish Chrome Sales During the Second World War", Middle Eastern Studies, Vol.42, No.6, 2007, s. 907-915.

TAMKIN, Nicholas, "Diplomatic Sigint and the British Official Mind during the Second World War: Soviet Claims on Turkey, 1940-1945”, Intelligence and National Security, Vol.23, No.6, 2009, s. 749-766.

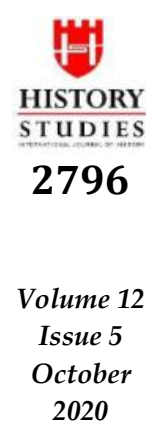

